\title{
In vivo analysis of highly conserved Nef activities in HIV-1 replication and pathogenesis
}

\author{
Richard L Watkins, Wei Zou, Paul W Denton, John F Krisko, John L Foster ${ }^{*}$ and J Victor Garcia*
}

\begin{abstract}
Background: The HIV-1 accessory protein, Nef, is decisive for progression to AIDS. In vitro characterization of the protein has described many Nef activities of unknown in vivo significance including CD4 downregulation and a number of activities that depend on Nef interacting with host SH3 domain proteins. Here, we use the BLT humanized mouse model of HIV-1 infection to assess their impact on viral replication and pathogenesis and the selection pressure to restore these activities using enforced in vivo evolution.

Results: We followed the evolution of HIV-1 LAI (LAI) with a frame-shifted nef (LAINeffs) during infection of BLT mice. LAINeffs was rapidly replaced in blood by virus with short deletions in nef that restored the open reading frame (LAINeffs $\Delta-1$ and LAINeffs $\Delta-13$ ). Subsequently, LAINeffs $\Delta-1$ was often replaced by wild type LAl. Unexpectedly, LAINeffs $\Delta-1$ and LAINeffs $\Delta-13$ Nefs were specifically defective for CD4 downregulation activity. Viruses with these mutant nefs were used to infect BLT mice. LAINeffs $\Delta-1$ and LAINeffs $\Delta-13$ exhibited three-fold reduced viral replication (compared to LAl) and a 50\% reduction of systemic CD4 ${ }^{+}$T cells (>90\% for LAl) demonstrating the importance of CD4 downregulation. These results also demonstrate that functions other than CD4 downregulation enhanced viral replication and pathogenesis of LAINeffs $\Delta-1$ and LAINeffs $\Delta-13$ compared to LAINeffs. To gain insight into the nature of these activities, we constructed the double mutant P72A/P75A. Multiple Nef activities can be negated by mutating the SH3 domain binding site (P72Q73V74P75L76R77) to P72A/P75A and this mutation does not affect CD4 downregulation. Virus with nef mutated to P72A/P75A closely resembled the wild-type virus in vivo as viral replication and pathogenesis was not significantly altered. Unlike LAINeffs described above, the P72A/P75A mutation had a very weak tendency to revert to wild type sequence.
\end{abstract}

Conclusions: The in vivo phenotype of Nef is significantly dependent on CD4 downregulation but minimally on the numerous Nef activities that require an intact SH3 domain binding motif. These results suggest that CD4 downregulation plus one or more unknown Nef activities contribute to enhanced viral replication and pathogenesis and are suitable targets for anti-HIV therapy. Enforced evolution studies in BLT mice will greatly facilitate identification of these critical activities.

Keywords: HIV-1, Nef, Replication, Pathogenesis, BLT humanized mice, Mutation

\section{Background}

Patients infected with nef-defective HIV-1, have strongly attenuated viral replication and pathogenesis [1-4]. In vitro studies have defined numerous Nef activities but how this 206 amino acid protein has such a major effect on the outcome of HIV-1 infection in patients is unknown [5-9]. One view of Nef's overall impact on HIV-1 infection is that there is a cumulative effect of multiple

\footnotetext{
* Correspondence: john_foster@med.unc.edu; victor_garcia@med.unc.edu Division of Infectious Diseases, Center for AIDS Research, 2042 Genetic Medicine, University of North Carolina, Campus Box 7042, Chapel Hill, NC 27599-7042, USA
}

(c) 2013 Watkins et al.; licensee BioMed Central Ltd. This is an open access article distributed under the terms of the Creative Commons Attribution License (http://creativecommons.org/licenses/by/2.0), which permits unrestricted use, distribution, and reproduction in any medium, provided the original work is properly cited. activities to achieve high viral loads resulting in the development of AIDS [10,11]. In support of this view, a number of Nef activities have been found to be conserved in monkey, ape and human immunodeficiency viruses [12-17]. A difficulty with this interpretation is that there are so many Nef activities that the effect of any given activity on replication and pathogenesis would be small. Alternatively, one or a few Nef functionalities may be the major contributors to viral replication and pathogenesis. In this regard CD4 downregulation, a highly conserved Nef function, is of particular interest. Ex vivo studies with activated peripheral blood T cells and cultures 
of tonsil tissue support a dominant role for CD4 downregulation in establishing high rates of viral replication [18-20]. Another factor that may be critical is the SH3 domain binding site in Nef's polyproline helix [21-23]. This ten amino acid segment (PVRPQVPLRP) is the most highly conserved stretch of amino acids in the protein [24]. Evidence exists for SH3 domain binding site involvement with enhanced viral replication [21,23,25], cytotoxic effects [26-30], activation of Hck [31] and antagonism of host immune responses [32-36]. Nef structure/function studies have documented that the CD4 downregulation activity and the $\mathrm{SH} 3$ domain protein dependent activities are genetically distinct $[21,37,38]$.

To gain greater understanding of the roles of Nef's diverse activities during HIV-1 replication we have employed the BLT humanized mouse model. This model has stable reconstitution of a full spectrum of human immune cells and has been used to investigate a number of different aspects of HIV-1 infection [39-44]. With regard to Nef, we have previously compared the replicative properties of HIV-1 $1_{\text {LAI }}$ (LAI) and LAI with two large deletions in nef coding sequence (LAINefdd) in BLT humanzed mice [44]. LAI exhibited high levels of viral replication and near total depletion of $\mathrm{CD}^{+}{ }^{+} \mathrm{T}$ cells in blood and tissues, as well as, depletion of $\mathrm{CD}^{+} \mathrm{CD}^{+}$thymocytes from the human thymic organoid. LAINef $d d$ had significantly reduced viral replication and dramatically reduced capacity for inducing $\mathrm{CD}^{+}{ }^{+} \mathrm{T}$ cell and $\mathrm{CD}^{+} \mathrm{CD}^{+}$thymocyte loss [44]. However, one important aspect of HIV-1 infection of BLT humanized mice that has not yet been investigated is the ability of nef to evolve during HIV-1 infection. In patients, HIV-1 nef extensively mutates resulting in tremendous sequence diversity but it has not been possible to clearly relate these changes to Nef activities or the pathogenic potential of the virus $[24,45-49]$. Here, we investigate three critical features of Nef's role during HIV-1 infection: 1) the ability of the virus to mutate nef sequences to gain enhanced replicative fitness, 2) the role of CD4 downregulation in viral replication and pathogenesis and 3) the importance of Nef's interactions with host SH3 domain proteins in replication and pathogenesis. We find that Nef induced CD4 downregulation is highly significant for active viral replication and pathogenesis. In addition, there are unidentified function(s) that contribute to viral replication and/or CD4 ${ }^{+} \mathrm{T}$ cell depletion and are necessary for Nef's full pathogenic potential. Importantly, this latter function or functions does not depend on interactions with host cell SH3 domain proteins.

\section{Results}

With the exceptions of vif and pol, the ability of HIV-1 to correct defective genes in vivo and regain function has not been investigated [50,51]. Determining the selection pressure for Nef functions is a key component for characterizing the overall importance of Nef and the phenotypic contribution of its individual activities. In addition, it provides an opportunity to use enforced selection to discern what structural/functional motifs of Nef are important in vivo. To address the mutational response of the virus to a defective nef, we generated an inactivating mutation by filling in the $5^{\prime}$ four-base overhang generated by the XhoI restriction endonuclease at codon 35 with Klenow (Figure 1A and Additional file 1). This insertion resides $5^{\prime}$ of the polypurine tract and does not alter the synthesis of gag encoded proteins (Figure 1B) or alter the in vitro replication properties of the virus (Figure 1C).

LAI and the nef frame-shifted LAI (LAINeffs) were injected intravenously (iv, 360,000 TCIU) into BLT mice. Three LAI infected mice were monitored over eight weeks for virus in the blood. These mice had peak viral loads of $12.2 \pm 4.7 \times 10^{6}$ copies of viral RNA. No changes were observed in nef sequence after eight weeks of the infection (Figure 2A). The LAINeff $s$ inoculated mice were also monitored longitudinally for the presence of virus in plasma. LAINef $f s$ infected mice exhibited active viral replication with peak viral loads of $2.26 \pm 0.72 \times 10^{6}$ copies of viral RNA per $\mathrm{ml}$ of blood $(\mathrm{n}=7)$. We sequenced $n e f$ from viral RNA in blood from two to eight weeks post-infection and found that the frame-shifted LAINeffs (designated "+4") was initially replaced by one of two nef sequences with restored open reading frames (Figure 2A). One mouse (LAINeff $s$ 1) had a thirteen base deletion downstream of the original four base insertion $(\Delta-13)$. In the other six cases (LAINeffs 2-7), the nef coding sequence also retained the four base insertion but lost one base in a run of five adenines just downstream of the original insertion site $(\Delta-1)$. The original LAINef $f(+4)$ was not detectable in blood by five weeks post infection in any of the seven mice. In two mice, and by a slower process, wild type nef appeared by 4-7 weeks (LAINeffs 4, 5). After eight weeks, four mice (LAINeffs 3, 4, 5 and 6) were predominantly infected with a virus containing wild type nef (not shown). In summary, in the blood of all of the mice inoculated with LAINeffs the original defective nef was replaced by a nef mutant that restored the open reading frame. Sequences determined at eight weeks yielded four mice with exact removal of the four base insertion (WT), two mice with $\Delta-1$ and one mouse with $\Delta-13$. These results support the conclusion that a strong positive selection exists for a functioning nef.

The amino acid sequences of the restored nefs are reported in Figure 2B. The changes in Nef sequence resulting from the one base deletion (LAINeff $s \Delta-1$ ) and the thirteen base deletion (LAINeffs-13) were the replacement of three amino acids (DLE, 36-38) in wild type LAINef with four missense amino acids (SRPG) and the replacement of ten wild type amino acids (DLEKHGAITS, 36-45) 


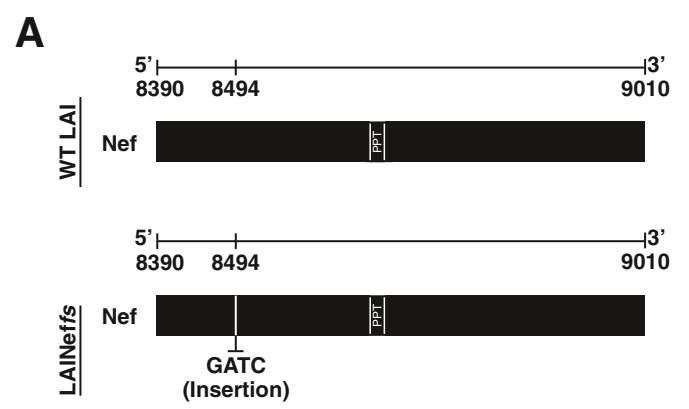

B

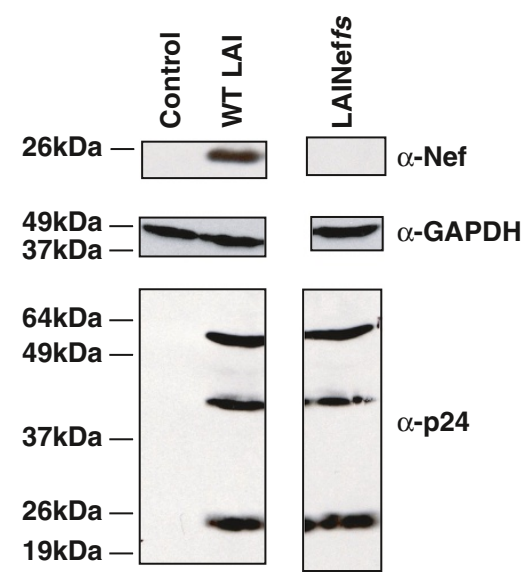

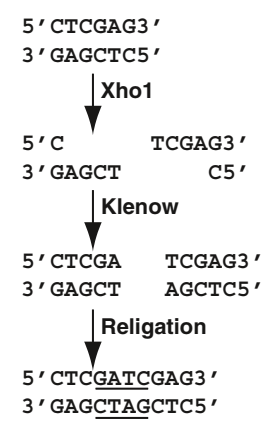

C

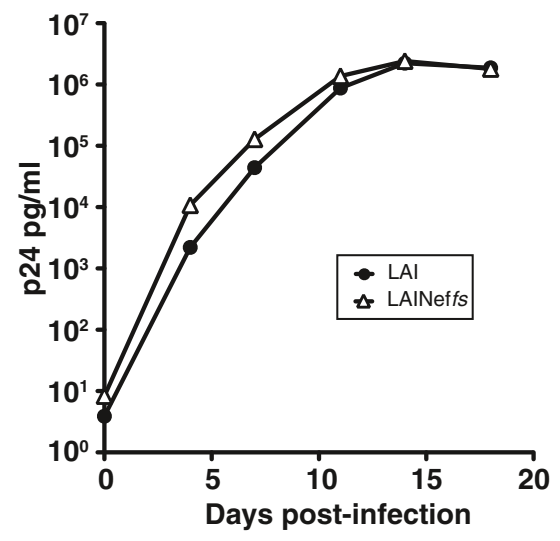

Figure 1 A frame shift in nef ablates expression of Nef but does not affect viral replication. (A) Upper Panel, Left, Schematic representation of wild type LAI (WT LAI) is presented. Nucleotides 8390 to 9010 in NCBI accession number, K02013, represent the nef coding sequence. Lower Panel, Left, A schematic of frame shifted nef (LAINeffs) is presented. The insertion of GATC following nucleotide 8494 is indicated. PPT, polypurine tract. Upper Panel, Right, Flow chart describing the generation of the GATC insertion is presented. (B) The frame shift in nef eliminates Nef expression but does not alter the expression of Gag. nef (a-Nef) and gag (a-p24) encoded proteins were detected by Western blot analysis of 293T producer cell lysates. GAPDH (a-GAPDH) is a protein loading control. (C) A3.01 cells were infected with LAl or LAINeffs at a multiplicity of infection of 0.05 and viral production was followed for 20 days with ELISA for p249ag.

with seven missense amino acids (SRPGKTC), respectively (Figure 2B). The sequencing data suggested that virus with $f_{s} \Delta-1$ and $f_{s} \Delta-13$ nefs had a strong replicative advantage over the nef-defective virus. However, the replacement of LAINeff $s \Delta-1$ with wild type (WT) virus in four mice further suggests a replicative advantage for wild type nef over revertant nefs. Based on these in vivo findings, we were interested in characterizing the in vitro activities of the $\Delta-1$ and $\Delta-13$ mutant Nefs.

\section{In vitro functional analysis of nef mutants that evolved in vivo}

To assess in vitro phenotypes of the Nefs expressed by LAINef $f s-1$ and LAINef $f \Delta-13$, we transferred the coding sequences into the retroviral expression plasmid, pLXSN, and produced retroviral vectors [52]. CEM T cells expressing wild type and mutant Nefs were assayed for level of expression, CD4 downregulation and $\mathrm{MHC}$ Class I (MHCI) downregulation activities (Figure 3A).
The mutant forms of Nef were expressed at the same level as wild type Nef (Figure 3A, Upper Panel, $\alpha-\mathrm{Nef}$ ). Flow cytometric analysis of cell surface CD4 and $\mathrm{MHCI}$ expression of CEM T cells that were transduced to express LAI Nef yielded the well-known patterns for the downregulation of these proteins (Figure 3A, Lower Panel, [21,52,53]). Both LAI Neff $s \Delta-1$ and LAI Neff $s \Delta$ 13 proteins were fully active for $\mathrm{MHCI}$ downregulation but devoid of CD4 downregulation activity. To assess the effect of the two mutations on Nef's interaction with p21 activated protein kinase (PAK2), we expressed the $\operatorname{Nef} f s \Delta-1$ and $\operatorname{Nef} f s \Delta-13$ proteins from pcDNA3.1 in transfected $293 \mathrm{~T}$ cells. We determined the capacity of these Nefs to activate PAK2 using an in vitro kinase assay (IVKA, [21,54,55]). Again, both mutant proteins were expressed at the same level as wild type LAI Nef (Figure 3B, $\alpha-\mathrm{Nef}$ ) and both proteins activated PAK2 although at a reduced level for LAI Neff $s \Delta-13$ (Figure 3B, $\alpha$-PAK2 IVKA). We also generated the proviral clones, 


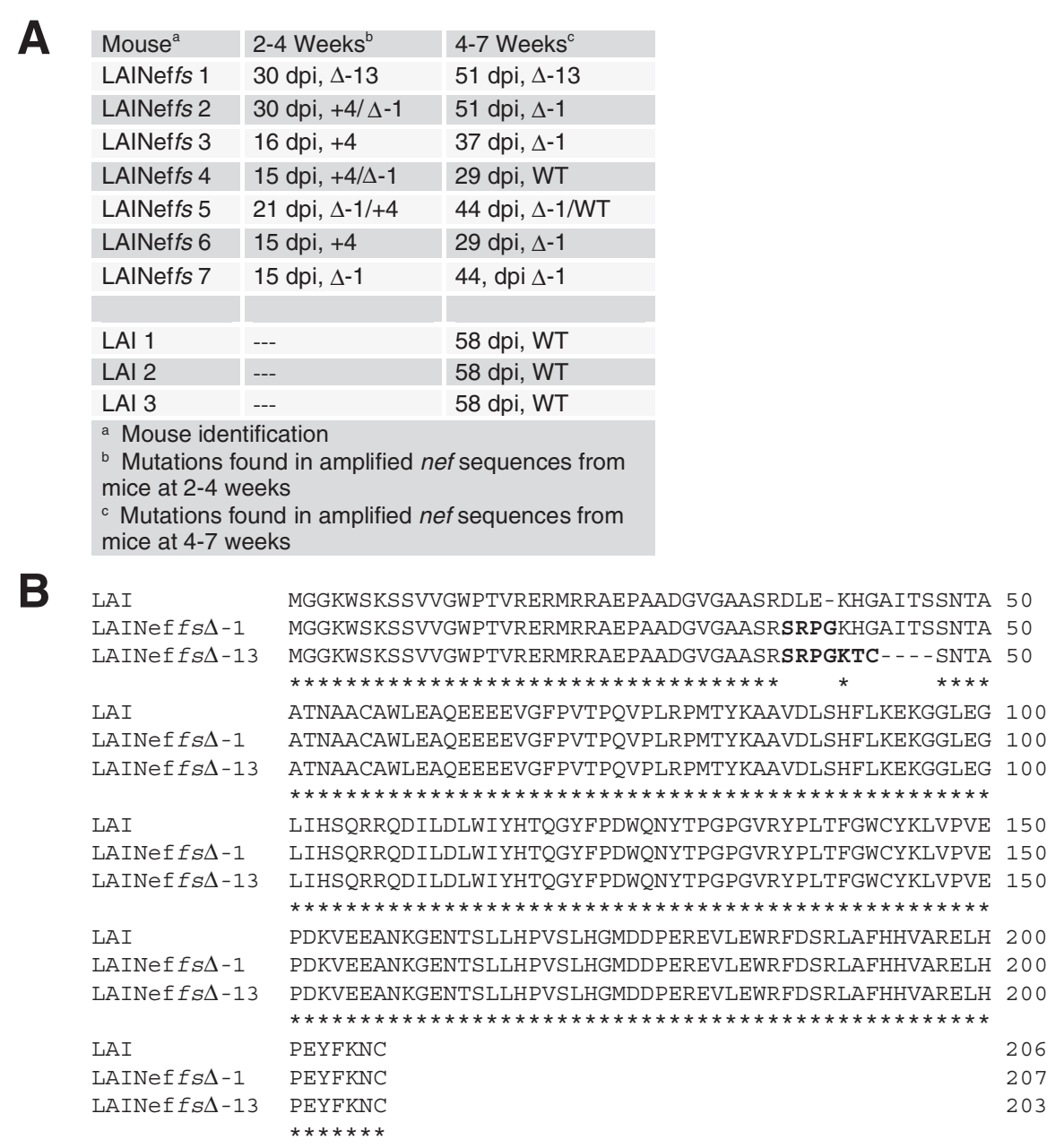

Figure 2 LAINeffs mutates to have one of three nefs with an open reading frame. (A) At several time points during the eight week infection, viral RNA was reverse transcribed from plasma. After amplification by PCR, nef was sequenced. By four weeks, six of seven mice exhibited nef sequence with a one base deletion just downstream of the four base insertion in a run of five adenines. This one base deletion $(\Delta-1)$ restored the nef reading frame. In the remaining mouse, a 13 base deletion occurred downstream of the four base insertion $(\Delta-13)$ which also restored the nef open reading frame. Three of the seven mice had a mixture of two different sequences in plasma which are indicated by the "majority sequence/the minority sequence." By seven weeks, there were two mice with reversions to wild type sequence (WT) by the removal of four inserted bases from CTCGATCGAG to yield CTCGAG. +4 , nef with the original four base insertion intact. (B) The conceptual translations of the LAINeffs $\Delta-1$ and LAINeffs $\Delta-13$ mutated nefs are aligned with wild type LAI Nef amino acid sequence. Bold indicates missense amino acids encoded by LAINeffs $\Delta-1$ and LAINeffs $\Delta-13$.

pLAINeff $s \Delta-1$ and pLAINeffs $\Delta-13$, to characterize the enhancement of infectivity function of these Nefs. Virus was produced from transfected $293 \mathrm{~T}$ cells and assayed with HeLa MAGI indicator cells. In this single infection assay, a reduction in the number of infected cells per ng of virion $\mathrm{p} 24^{g a g}$ is observed for LAINeffs relative to LAI (Figure 3C). LAINef $f \Delta-1$ and LAINef $f \Delta-13$ both exhibited higher infectivities than LAINef $f s$ in this assay but were not significantly different from LAI (Figure 3C). Finally, in Figure 3D, the capacities of LAINeff $s \Delta-1$ and LAINeffs $\Delta-13$ to replicate in A3.01 cells were observed to be the same as LAI (Figure 3D). On the basis of this data, we concluded that LAINeff $s \Delta-1$ and LAINef $f s \Delta-13$ exhibited a specific loss of the CD4 downregulation activity and were potentially useful to investigate the impact of CD4 downregulation by Nef on HIV-1 infection in BLT mice. However, the question remained whether these nefs could revert to wild type sequence in vivo as four of seven mice infected with LAINeffs had predominantly the wild type nef sequence in blood after eight weeks (Figure 2A). It should be noted that reversion of the $\Delta-1$ mutation to wild type would require two steps, a four-base deletion and a one base insertion of adenosine. We judged this two-step process to be unlikely to occur within the time frame of the experiments. Accordingly, the wild type nefs found in four of the seven mice 


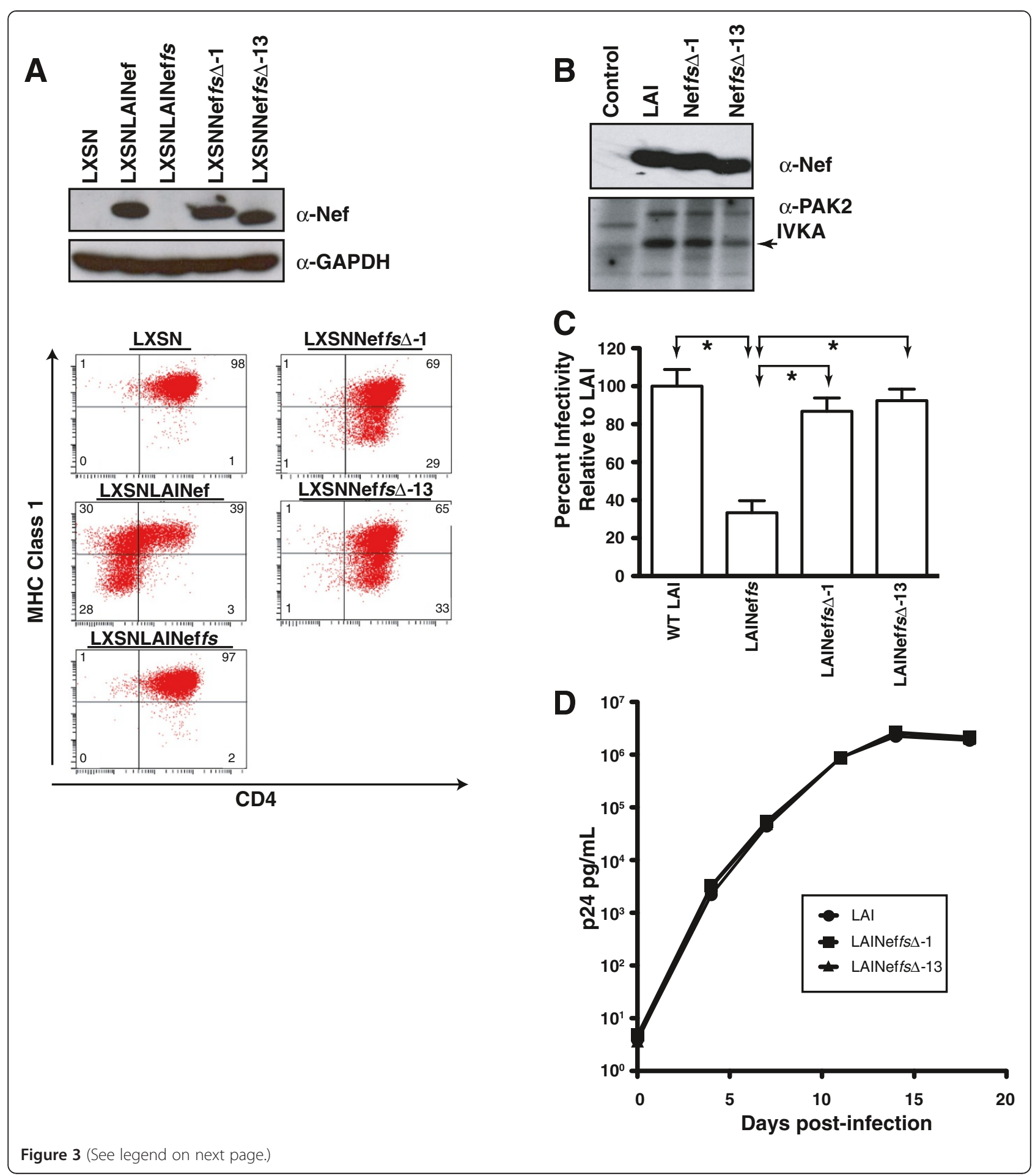


(See figure on previous page.)

Figure 3 LAINeffs $\Delta-1$ and LAINeffs $\Delta-13$ encode Nefs that are specifically defective for downregulating surface expression of CD4. (A) Nefs encoded by LAINeffs $\Delta-1$, LAINeffs $\Delta-13$ and LAI were expressed in CEM cells following transduction with retroviral vectors (LXSN). Upper Panel, A Western blot demonstrates LAI Neffs $\Delta-1$ and LAI Neffs $\Delta-13$ were expressed at comparable levels as wild type (a-Nef). LXSN and LXSNNeffs served as negative controls. GAPDH is a protein loading control (a-GAPDH). Lower Panel, CEM cells expressing LAI Nef, LAI Neffs, LAI Neffs $\triangle-1$ and LAI Neffs $\triangle-13$ were analyzed by flow cytometry for cell surface CD4 and MHC Class I (MHCl) expression. LXSNLAINef was the positive control. LXSN and LXSNLAINeffs were negative controls. Percentage of cells in each quadrant out of total cells is indicated. (B) Nefs encoded by LAI, LAINeffs $\Delta-1$ and LAINeffs $\Delta-13$ were expressed in transfected 293T cells. Control, 293T cells transfected with empty vector. Upper Panel, Lysates from transfected cells were analyzed by Western blot (a-Nef). Lower Panel, Total p21 activated protein kinase-2 (PAK2) in lysates of transfected cells lysates were immunoprecipitated with anti-PAK2 antiserum (a-PAK2) and analyzed by the in vitro kinase assay (IVKA). Control cells had no activated PAK2. Arrow, autophosphorylated PAK2. (C) pLAl, pLAINeffs, pLAINeffs $\Delta-1$ and pLAINeffs $\Delta-13$ proviral clones were transfected into $293 T$ cells and virus harvested from the media. LAl, LAINeffs, LAINeffs $\Delta-1$ and LAINeffs $\Delta-13$ were titered using HeLa-MAGl indicator cells [82] and p24 ${ }^{\text {gag }}$ contents were quantified by ELISA. Infectivities (blue cells per ng p24 ${ }^{g a g}$ ) from six determinations of each virus were normalized relative to LAI (100\%). Significant comparisons are indicated by lines and arrows above respective bars $\left(^{*}, p<0.05\right)$. (D) A3.01 cells were infected with LAl, LAINeffs $\Delta-1$ and LAINeffs $\Delta-13$ at multiplicity of infection of 0.05 and viral production followed for 20 days with ELISA for p2 $4^{\text {gag }}$.

by week eight may have been directly generated from the frame-shifted nef in LAINeffs by the exact removal of the four-base insertion (Additional file 1).

\section{Infection of BLT humanized mice with in vivo generated nef mutations}

LAI, LAINeff $s \Delta-1$ and LAINeff $s \Delta-13$ were intravenously injected (90,000 TCIU) into BLT mice. In Figure 4, the positive control, wild type LAI, and the negative control, uninfected mice (Naïve), are compared to LAINeff $s \Delta-1$ and LAINeff $s \Delta-13$ infected mice. In Figure $4 \mathrm{~A}$ and $\mathrm{C}$, LAI inoculation was followed with rapid appearance of viral RNA in blood and replication to high levels (peak viral loads, $3.03 \pm 0.54 \times 10^{6}$ copies viral RNA per $\mathrm{ml}$ of plasma, $\mathrm{n}=7$ ). The time course for the infections with LAINeff $s \Delta-1$ and LAINeff $s \Delta-13$ revealed a reduction in viral replication compared to LAI (Figure 4A and C). The average peak viral load (in millions of RNA copies

\section{A}

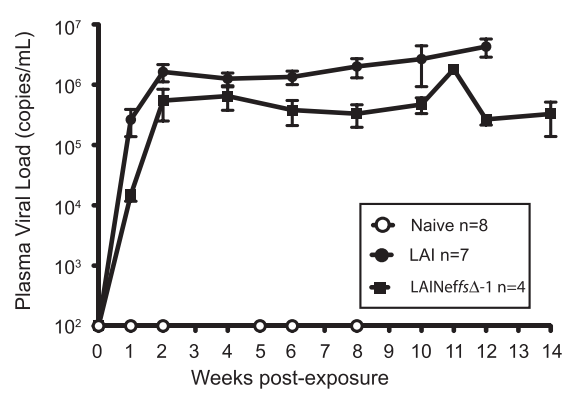

C

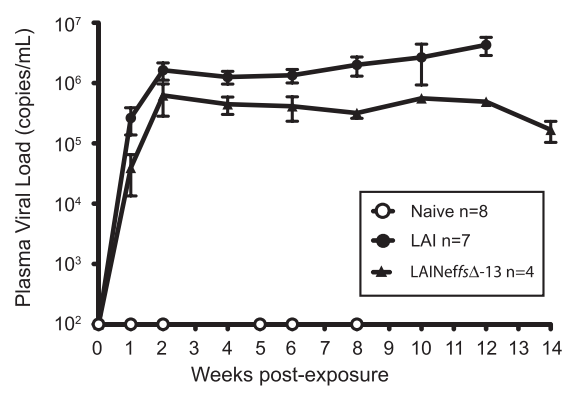

B

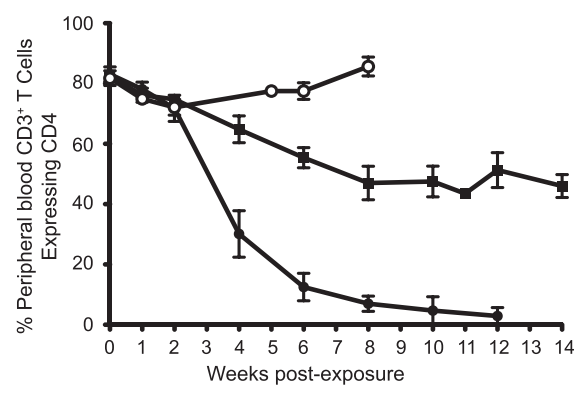

D

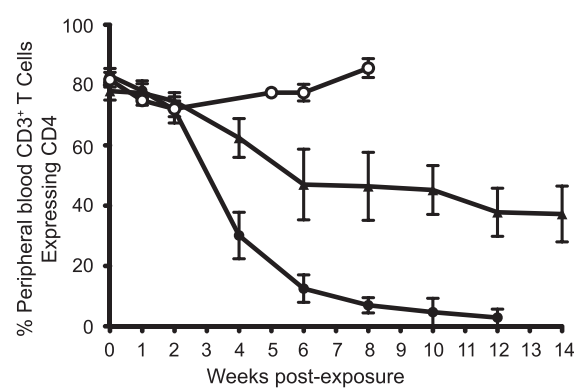

Figure 4 Viral load analysis and peripheral blood $\mathrm{CD}^{+} \mathbf{T}$ cell depletion in mice infected with LAI. (A) Viral loads (copies of LAI RNA per milliliter of plasma) of BLT humanized mice exposed to 90,000 TCIU of LAI or LAINeffs $\Delta-1$ were plotted. Uninfected mice (Naïve) served as negative controls (open circle, $n=8$ ); LAI (filled circle, $n=7$ ); and LAINeffs $\Delta-1$ (filled square, $n=4$ ). (B) Plot of percent peripheral blood $C D 3^{+} T$ cells expressing CD4. Naïve mice, LAI and LAINeffs $\Delta-1$ as in (A). (C) Viral loads were plotted following inoculation of 90,000 TCIU of LAI or LAINeffs $\Delta$-13. Naïve mice as negative controls (open circle, $n=8$ ); LAI (filled circle, $n=7$ ); and LAINeffs $\Delta-13$ (filled triangles, $n=4$ ). (D) Plot of percent peripheral blood CD3 ${ }^{+} T$ cells expressing CD4. Naïve mice, LAl and LAINeffs $\Delta-13$ as in (C). 
per $\mathrm{ml}$ of peripheral blood) for $\operatorname{LAINef} f_{s} \Delta-1$ was $1.19 \pm$ $0.26(n=4)$ which was significantly different from LAI (Figure 4A, $3.03 \pm 0.54(n=7) ; p=0.0242)$. Similarly, in Figure $4 \mathrm{C}$, the average peak viral load for LAINef $f \Delta-13$ was lower than LAI $(0.93 \pm 0.23(\mathrm{n}=4) ; \mathrm{p}=0.0061)$. Thus, there appears to be about a threefold reduction in peak viral load relative to wild type for LAINeffs $\Delta-1$ and LAINeff $s \Delta-13$.

During infection with LAI, CD4 ${ }^{+} \mathrm{T}$ cell levels in blood were dramatically reduced (Figure $4 \mathrm{~B}$ and D) while $\mathrm{CD} 4^{+}$ $T$ cells in the blood of uninfected mice were maintained at approximately $80 \%$ of total blood T cells (Figure $4 \mathrm{~B}$ and $\mathrm{D})$. For LAI, the average time to reduce $\mathrm{CD}^{+} \mathrm{T}$ cells to $50 \%$ of total blood $\mathrm{T}$ cells was $21.6 \pm 2.4$ days post infection (dpi, $\mathrm{n}=7$ ). For mice inoculated with LAINeff $s \Delta-1$ or LAINeff $s \Delta-13$, an intermediate loss of $C D 4^{+} \mathrm{T}$ cells was evident (Figure $4 \mathrm{~B}$ and $\mathrm{D}$ ). The time for $\mathrm{CD} 4^{+} \mathrm{T}$ cells in blood to decline to $50 \%$ of total $\mathrm{T}$ cells was determined and compared to LAI (Figure $4 \mathrm{~B}$ and D). As noted, LAI gave $21.6 \pm 2.4 \mathrm{dpi}(\mathrm{n}=7)$ which was significantly shorter than LAINef $f_{s} \Delta-1$ at $65.1 \pm 13.4 \mathrm{dpi}(\mathrm{n}=4, \mathrm{p}=0.0106)$ and LAINeffs $\Delta-13$ at $52.5 \pm 13.5 \mathrm{dpi}(\mathrm{n}=4, \mathrm{p}=0.0294)$. LAI$\operatorname{Nef} f s-1$ and LAINeff $s \Delta-13$ infected mice were not statistically different from each other. Together, the results from Figure 4 document an intermediate in vivo Nef phenotype for LAINeff $s \Delta-1$ and LAINef $f s \Delta-13$.

We have previously reported the phenotypes of LAI and LAI with a totally inactivated nef (LAINefdd, [44]). The observation that LAI expressing a Nef specifically defective for CD4 downregulation has an intermediate phenotype not expected based on previous reports [18,19,56]. In support of this conclusion, we also observed that a partial loss of $\mathrm{CD}^{+} \mathrm{T}$ cells from blood is established by six weeks. At this time point, the percent of $\mathrm{CD} 4^{+} \mathrm{T}$ cells in LAINeff $s \Delta-1$ and LAINeff $s \Delta-13$ infected mice were significantly lower than in Naïve mice but significantly higher than in LAI-infected mice (Figure $4 \mathrm{~B}$ and D). For LAI$\operatorname{Nef} f_{s} \Delta-1$ inoculated mice, the percent $\mathrm{CD}^{+} \mathrm{T}$ cells of total $T$ cells present in blood was $55.4 \pm 3.3(n=4)$ compared to $77.5 \pm 2.8(\mathrm{n}=4)$ for Naïve (Figure $4 \mathrm{~B})$ with $\mathrm{p}=$ 0.0286 . For LAINeff $s \Delta-13$ inoculated mice, the percentages were $47.0 \pm 11.7(n=4)$ versus $77.5 \pm 2.8(n=4)$ with $\mathrm{p}=0.0286$. Also at six weeks, LAINeffs $s-1$ and LAINeff $s \Delta-13$ infected mice had higher percentages of $C D 4^{+}$ $T$ cells than LAI infected mice (Figure $4 \mathrm{~B}$ and D). Percent of CD4 $4^{+}$T cells for LAI was $12.5 \pm 4.5(n=6)$, versus $55.4 \pm$ $3.3(\mathrm{n}=4, \mathrm{p}=0.0095)$ for $\operatorname{LAINef} f_{S} \Delta-1$. Percent of CD $4^{+}$ $\mathrm{T}$ cells for LAI versus LAINeff $s \Delta-13$ was $12.5 \pm 4.5(\mathrm{n}=6)$ versus $47.0 \pm 11.7(\mathrm{n}=4, \mathrm{p}=0.0190)$.

At eight weeks, CD4 ${ }^{+} \mathrm{T}$ cells in blood of LAI infected mice are nearly depleted while Naïve mice maintained $\mathrm{CD}^{+}{ }^{+} \mathrm{T}$ cells at approximately $80 \%$ of total $\mathrm{CD}^{+} \mathrm{T}$ cells (Figure 4B and D, [44,57]). It was of interest to allow the LAINeff $s \Delta-1$ and LAINeff $s \Delta-13$ infections to continue past eight weeks to determine if these viruses would slowly deplete $\mathrm{CD}^{+}{ }^{+} \mathrm{T}$ cells from blood. By 14 weeks, substantial levels of $\mathrm{CD}^{+} \mathrm{T}$ cells were still evident in blood for both viruses which emphasizes the persistence of the partial Nef phenotype in the absence of CD4 downregulation (Figure 4B and D).

\section{Systemic loss of $\mathrm{CD}^{+} \mathrm{T}$ cells in BLT humanized mice infected with LAINeffs $\Delta-1$ and LAINeffs $\Delta-13$}

We previously observed that systemic loss of human $\mathrm{CD}^{+}{ }^{+} \mathrm{T}$ cells from organs closely paralleled loss of human $\mathrm{CD}^{+} \mathrm{T}$ cells from blood during infection with wild type (LAI) and nef-defective (LAINefdd ) virus [44,57]. For LAINeff $s \Delta-1$ and LAINef $f s \Delta-13$ infected mice, we also determined that the loss of $\mathrm{CD}^{+}{ }^{+} \mathrm{T}$ cells in peripheral blood is matched by the loss of these cells from bone marrow, lymph node, liver, lung and spleen (Figure 5A). Statistical analysis of Naïve versus LAI, LAINeff $s \Delta-1$ and LAINeffs $\Delta-13$ infected mice demonstrated significant losses in the percent of $\mathrm{CD}_{4}^{+} \mathrm{T}$ cells in the five tissues (fifteen comparisons to Naive, all gave $\mathrm{p}<0.05$ ). Also, the fraction of total $\mathrm{T}$ cells that were $\mathrm{CD} 4^{+}$was consistently higher in LAINeff $f_{s} \Delta-1$ infected mice compared to LAI (all five comparisons, $\mathrm{p}<0.05$ ). In the case of LAI$\operatorname{Nef} f_{s} \Delta-13$ versus LAI, three of five organs had statistically higher levels of $\mathrm{CD}^{+} \mathrm{T}$ cells in LAINef $f_{s} \Delta-13$ infected mice, with the higher levels of $\mathrm{CD} 4^{+} \mathrm{T}$ cells not reaching statistical significance for bone marrow and lymph node. The comparisons between LAINeff $f_{s} \Delta-1$ and LAINef $f s \Delta-13$ infected mice were not significantly different in any tissue. Therefore, the partial reduction of $\mathrm{CD}^{+} \mathrm{T}$ cells in blood seen with LAINeff $s \Delta-1$ and LAINeffs $\Delta-13$ infection is systemic.

We previously reported a devastating impact of LAI infection on $\mathrm{CD}^{+} \mathrm{CD}^{+}$thymocytes. However, LAI lacking a functional nef failed to reduce double positive thymocytes [44]. In Figure 5B, drastic depletion of $\mathrm{CD}_{4}^{+}$ $\mathrm{CD}^{+}$thymocytes was confirmed following inoculation with LAI. Intermediate losses were observed with LAINeff $s \Delta-1$ and LAINeff $s \Delta-13$ (Naive, $76.3 \pm 3.0 \%$; LAI, 1.7 $\pm 1.2 \%$; LAINeff $s \Delta-1,35.0 \pm 17.1 \%$; LAINeff $s \Delta-13,29.3 \pm$ $10.2 \%)$. On the basis of the above results, we conclude that the partial losses of LAINeff $s \Delta-1$ and LAINef $f_{s} \Delta-13$ found for $\mathrm{CD}^{+} \mathrm{T}$ cells appeared to extend to $\mathrm{CD} 4^{+} \mathrm{CD} 8^{+}$ thymocytes as well.

The mechanistic interpretation of the intermediate phenotype of the LAINeff $f_{s} \Delta-1$ and LAINeff $s \Delta-13$ viruses depends on the status of the sequence of nef. We sequenced $n e f$ in plasma virion RNA of LAINeff $s \Delta-1$ and LAINeff $s \Delta-13$ and found no reversions over the course of infection. Specifically, for LAINeff $s \Delta-1$, the four base insertion and the $\Delta-1$ deletion remained intact. For LAI$\operatorname{Nef} f s \Delta-13$, the four base insertion and the thirteen base deletion remained intact. There were no second site 

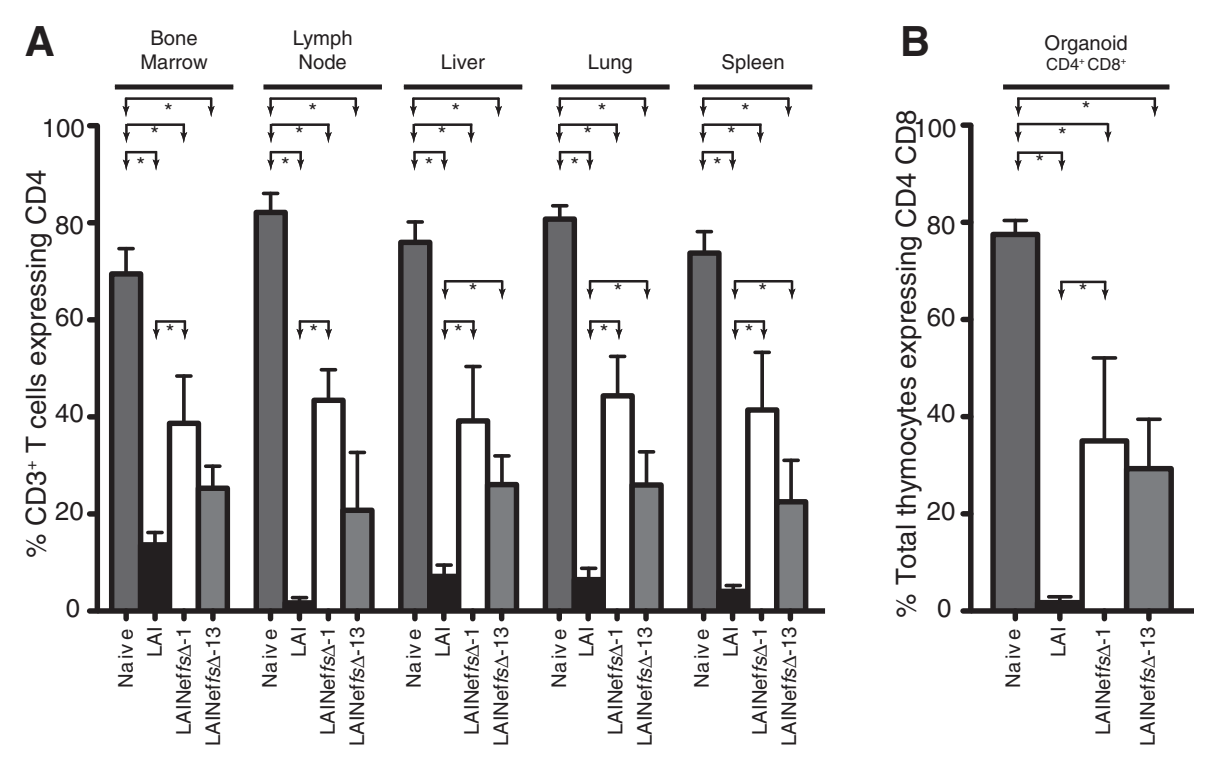

Figure 5 Analysis of CD4 ${ }^{+} \mathrm{T}$ cells from tissues in mice exposed to LAI, LAINeffs $\Delta-\mathbf{1}$ or LAINeffs $\Delta-13$. (A) Percent CD4 ${ }^{+} \mathrm{T}$ cells of total T cells in five organs from un-exposed BLT mice (Naive, $n=8)$ were compared to groups of BLT mice exposed to one of three viruses: $L A I(n=6)$, LAINeffs $\Delta-1(n=4)$, or LAINeffs $\Delta-13(n=4)$. Statistical comparisons reaching significance are indicated by lines and arrows above respective bars $\left({ }^{*}, p<0.05\right)$. (B) The same groups as in $(\mathbf{A})$ were compared for $C D 4^{+} C D 8^{+}$double positive thymocytes relative to total thymocytes.

mutations present in nef either (not shown). The absence of wild type nef sequence from LAINeff $s \Delta-1$ and LAINef $f s \Delta$-13 infected BLT mice implies the stability of the phenotypic properties of these two nefs during infection. This failure of $n e f s$ from LAINeff $s \Delta-1$ and LAI$\operatorname{Nef} f s \Delta-13$ to revert to wild type supports the hypothesis that the appearance of wild type nef sequence found in four of seven mice (Figure 2) infected with LAINef $f s$ was the result of an exact four base deletion and not a twostep removal of the four base insertion plus a one base addition (Additional file 1). Therefore, our investigations of LAINeff $s \Delta-1$ and LAINef $f_{s} \Delta-13$ demonstrate that LAIs stably lacking Nef's CD4 downregulation activity have the in vivo phenotype of a reduced capacity for viral replication, for $\mathrm{CD} 4^{+} \mathrm{T}$ cell depletion and for $\mathrm{CD} 4^{+}$ $\mathrm{CD}^{+}$thymocyte depletion relative to LAI [44].

\section{LAI, LAINeffs $\Delta-1$ and LAINeffs $\Delta-13$ and systemic T cell activation}

One explanation for the intermediate infection phenotypes of LAINef $f s \Delta-1$ and LAINef $f s \Delta-13$ would be an inability of these mutated HIV-1 to induce systemic T cell activation $[58,59]$. It has been previously reported that naïve BLT mice have approximately $2 \%$ of $\mathrm{CD}^{+} \mathrm{T}$ cells that are $\mathrm{CD}^{+} 8^{+}$ $\mathrm{HLA}^{-\mathrm{DR}^{+}}$double positive in blood. Infection with LAI or LAINefdd elevates this fraction to approximately $8 \%$ $[42,44]$. We observed similar effects of LAINeff $s \Delta-1$ and LAINeff $s \Delta-13$ infection on $\mathrm{T}$ cell activation. At six weeks post infection, LAINeff $s \Delta-1$ and LAINeffs $\Delta-13$ were determined to have $8.2 \pm 3.5 \%(n=4)$ and $6.1 \pm 2.3 \%(n=4)$ $\mathrm{CD} 8^{+} \mathrm{HLA}^{-\mathrm{DR}^{+}}$double positive $\mathrm{CD}^{+} \mathrm{T}$ cells in blood, respectively. Thus, LAINef $f_{s} \Delta-1$ and $\operatorname{LAINef} f s \Delta-13$ exhibit the same enhancements of peripheral blood T cell activation as LAI and LAINefdd.

\section{The role of $\mathrm{SH} 3$ domain dependent activities on LAI infection of BLT mice}

A large number of diverse activities of Nef have been shown to be dependent on the highly conserved SH3 domain binding site. We considered the possibility that these activities may account for the observed selective advantage of the LAINeff $s \Delta-1$ and LAINef $f s \Delta-13$ over LAINef $f s$ despite the absence the CD4 downregulation activity. SH3 domain-binding dependent activities are blocked by mutating two key prolines in Nef's polyproline helix (P72A/ P75A, [7,22]). To investigate the role of the P72A/P75A mutant Nef in vivo we generated isogenic, replication competent LAINefP72A/P75A. In 293T cells, LAINefP72A/ P75A expressed similar levels of Nef and p24 gag compared to LAI (Figure 6A) and actively replicated in A3.01 T cells (Figure 6B). We assayed the enhancement of virion infectivity for LAI and LAINefP72A/P75A and observed the expected loss of this activity for the $\mathrm{SH} 3$ domain binding site mutant (Figure 6C, [21,25,37]). Also, we expressed the mutated nef from LAINefP72A/P75A with the retroviral vector, LXSN, in CEM T cells and found it to be functional for CD4 downregulation but consistent with previous reports largely defective for MHCI downregulation (Figure 6D $[32,33,60])$. On the basis of these results, we concluded that infecting BLT mice with LAINefP72A/P75A would distinguish between the phenotypic impacts of SH3 domain binding protein dependent activities and CD4 downregulation. 

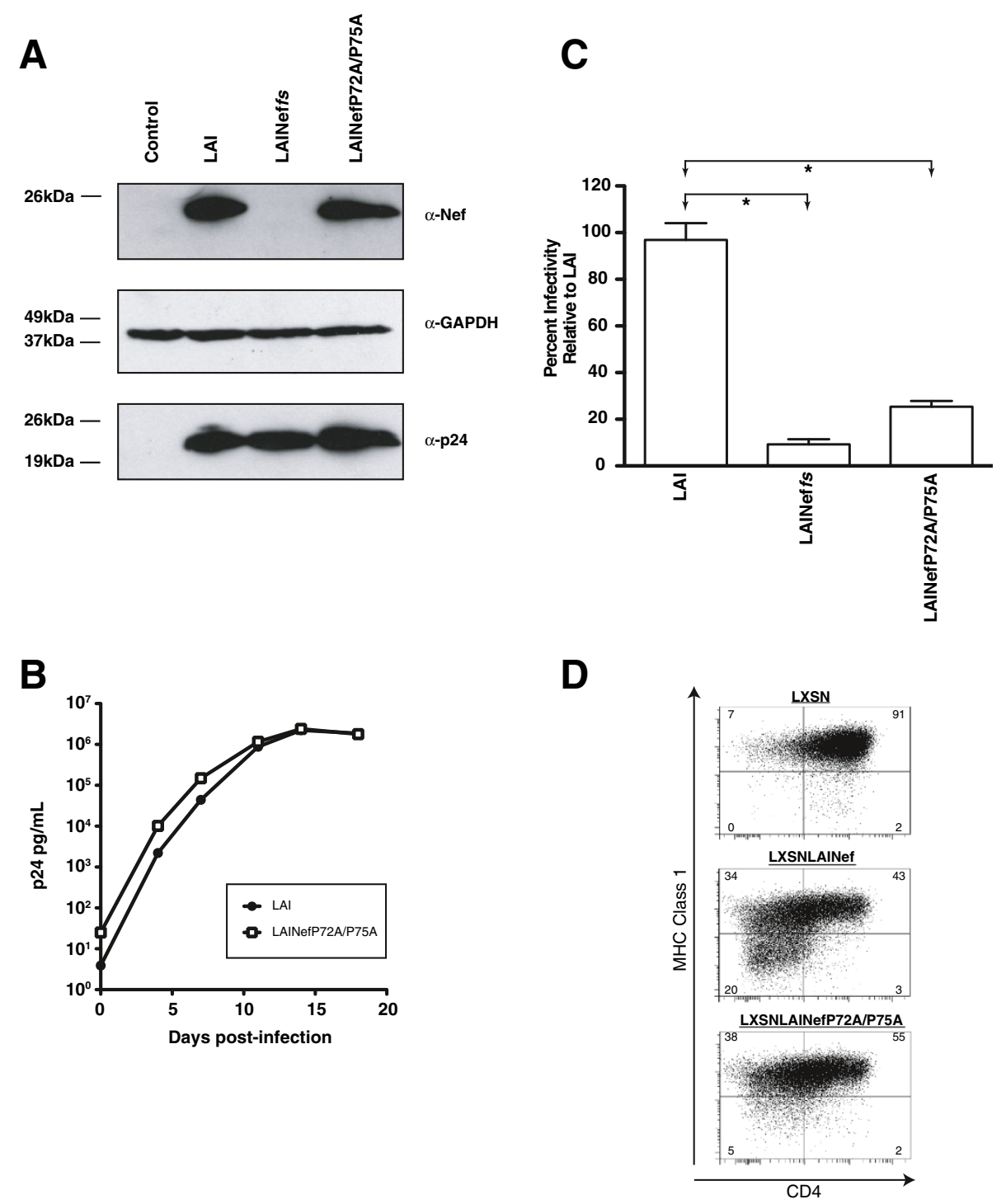

Figure 6 LAINefP72A/P75A replicates in A3.01 T cells and is functional for CD4 downregulation. pLAl, pLAINeffs and pLAINefP72A/P75A proviral clones were transfected into $293 \mathrm{~T}$ cells and virus harvested from the media. (A) Nef (a-Nef) and p24 ${ }^{\text {gag }}$ (a-p24) proteins were detected by Western blot analysis of 293T producer cell lysates. Control is non-transfected 293T cells. GAPDH (a-GAPDH) is a protein loading control. (B) A3.01 cells were infected with LAI and LAINefP72A/P75A at multiplicity of infection of 0.05 and viral production followed for 20 days with ELISA for p24 $4^{\text {gag }}$. (C) LAI, LAINeffs and pLAINefP72A/P75A were titered using HeLa-MAGI indicator cells [82] and p24 ${ }^{\text {gag }}$ quantitated by ELISA. Infectivities were normalized to LAI (100\%). (D) Nefs encoded by LAINefP72A/P75A and LAI were expressed in CEM cells following transduction with retroviral vectors (LXSN). CEM cells expressing LAI Nef and LAI NefP72A/P75A were analyzed by flow cytometry for cell surface CD4 and MHC Class I expression. LXSN is the negative control. Percentage of cells in each quadrant out of total cells indicated.

BLT mice were infected with 90,000 TCIU of LAINefP72A/P75A mutant virus (Figure 7). Under these experimental conditions, a 1.9-fold higher peak viral load was observed for LAINefP72A/P75A versus LAI (Figure 7A). This difference was not statistically different $(5.83 \pm 1.84$ ( $\mathrm{n}$ $=4)$ versus $3.03 \pm 0.54(\mathrm{n}=7) ; \mathrm{p}=0.1091)$. In addition, the P72A/P75A Nef mutant and the wild type virus showed a similar time course for reduction of peripheral blood $\mathrm{CD} 4^{+}$ $\mathrm{T}$ cells to $50 \%$ of total $\mathrm{T}$ cells in blood with LAINefP72A/ P75A at $29.5 \pm 4.1 \mathrm{dpi}(\mathrm{n}=4)$ versus LAI at $21.6 \pm 2.4 \mathrm{dpi}$ $(\mathrm{n}=7) ; \mathrm{p}=0.1554$ (Figure 7B). These results indicate that a functional SH3 domain binding site in Nef is not required in vivo for either high levels of virus replication or for $\mathrm{CD} 4^{+}$ $\mathrm{T}$ cell depletion.

\section{Systemic depeltion of $\mathrm{CD}^{+} \mathrm{T}$ cells and thymocytes by LAINefP72A/P75A}

In transgenic mice, it has been reported that expression of HIV-1 Nef from a CD4 promoter is cytotoxic to CD4 ${ }^{+}$ 


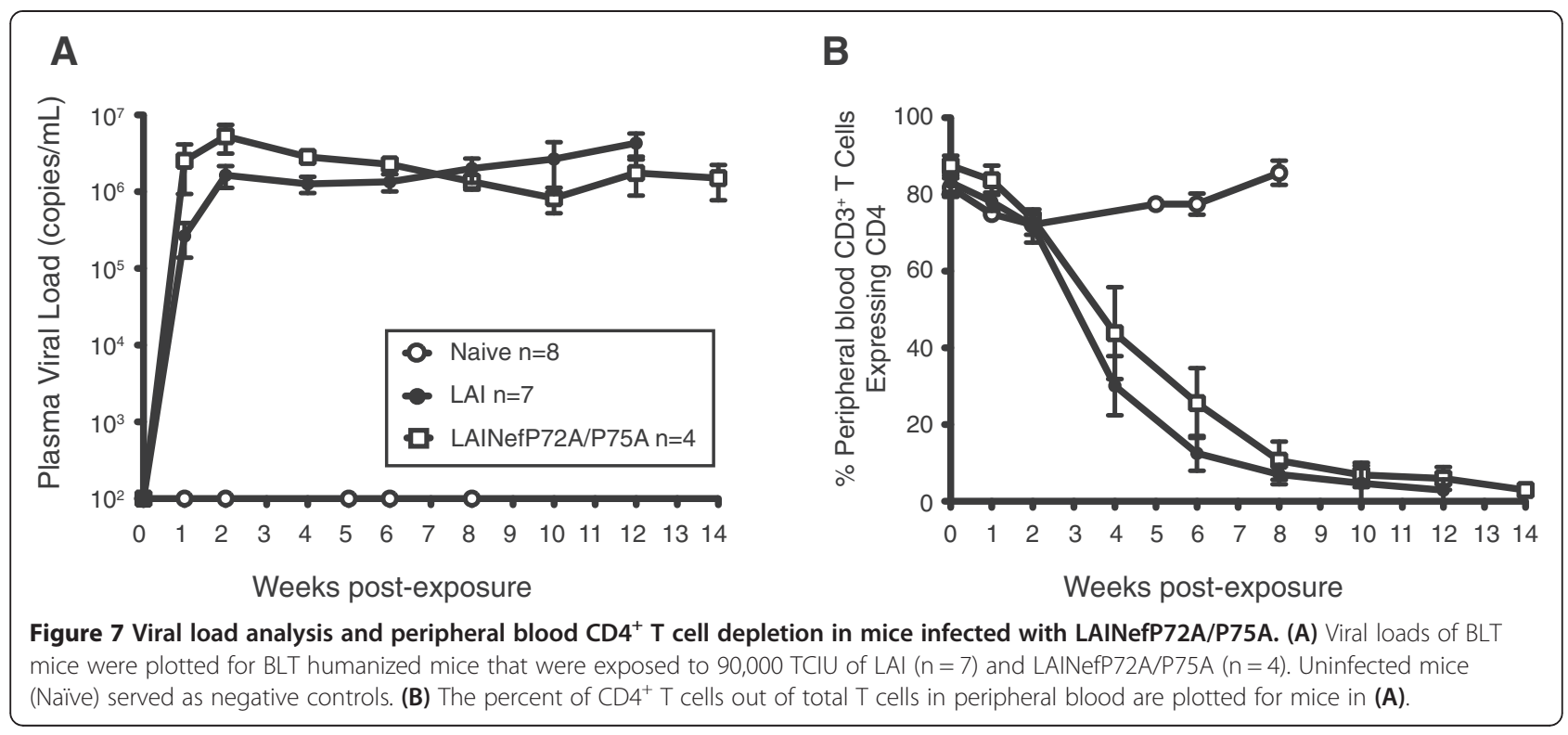

$\mathrm{T}$ cells in multiple organs [61]. In addition, this cytotoxic effect is lost when the polyproline helix is mutated [27]. Therefore, we determined the impact LAINefP72A/P75A infection in BLT mice on $\mathrm{CD} 4^{+} \mathrm{T}$ cells in bone marrow, lymph node, liver, lung and spleen (Figure 8A). LAI and LAINefP72A/P75A effectively depleted CD4 ${ }^{+}$T cells. All differences in levels of $\mathrm{CD} 4^{+} \mathrm{T}$ cells between Naïve mice and either LAI or LAINefP72A/P75A mice are statistically significant. In contrast, comparisons between the levels of residual $\mathrm{CD}_{4}^{+} \mathrm{T}$ cells in mice infected with LAI versus LAINefP72A/P75A were not significantly different (Figure 8A). $\mathrm{CD} 4^{+} \mathrm{CD}^{+}$thymocytes in the human thymic organoid were also analyzed. We found that these cells were efficiently depleted by LAINefP72A/P75A (Figure 8B). We, therefore, conclude that contrary to expectations the mutation, P72A/P75A has little to no effect on the systemic depletion of $\mathrm{CD} 4^{+} \mathrm{T}$ cells or $\mathrm{CD} 4^{+} \mathrm{CD} 8^{+}$thymocytes in vivo.
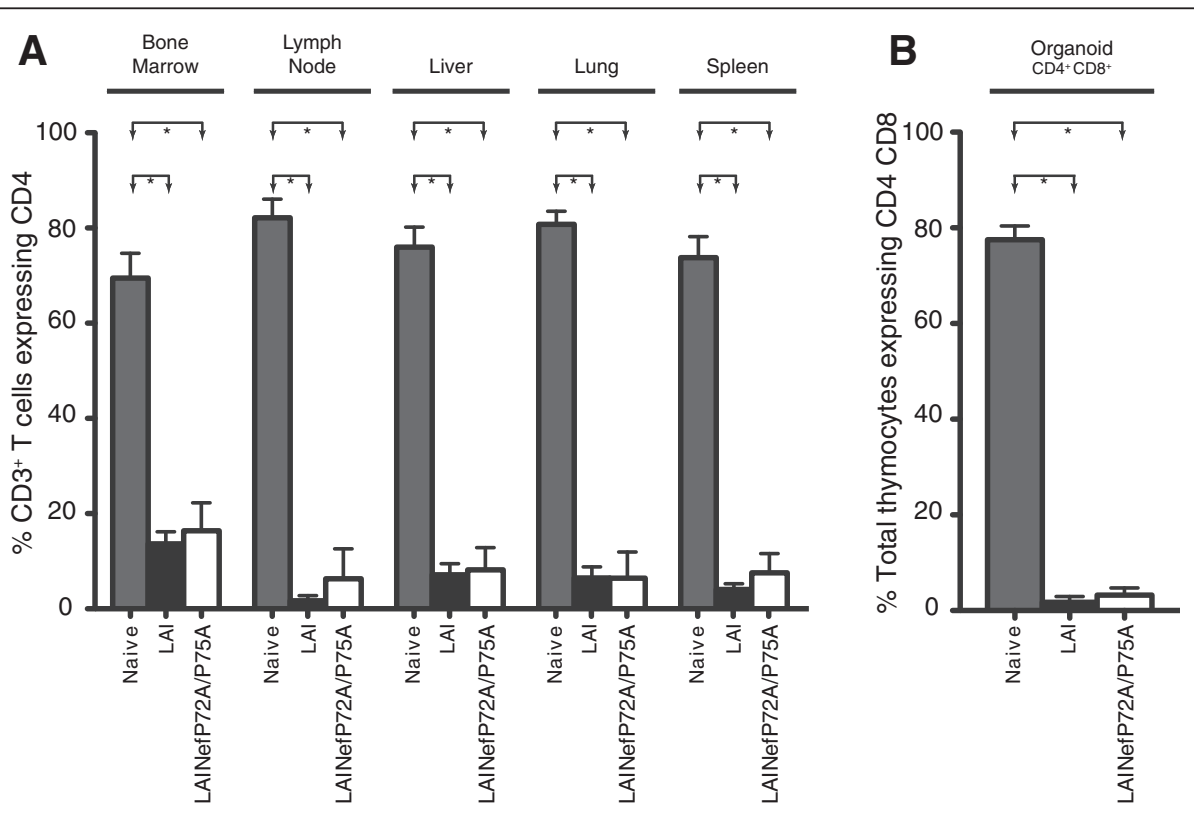

Figure 8 Analysis of $\mathrm{CD4}^{+} \mathrm{T}$ cells from tissues from mice exposed to LAI or LAINefP72A/P75A. (A) Percent of CD4 ${ }^{+} T$ cells out of total T cells from bone marrow, lymph node, liver, lung and spleen from unexposed BLT mice (Naive, $n=8$ ) were compared to groups of BLT mice exposed to LAI $(n=7)$ or LAINefP72A/P75A $(n=4)$. Statistical comparisons reaching significance are indicated by lines and arrows above respective bars ( $\left.{ }^{*}, p<0.05\right)$. (B) The same analysis as in $(A)$ is presented for $C D 4^{+} C D 8^{+}$double positive thymocytes relative to total thymocytes. Statistical comparisons reaching significance are indicated by lines and arrows above respective bars $\left({ }^{*}, \mathrm{p}<0.05\right)$. 


\section{In vivo selection pressure to correct the P72A/P75A mutation is weak}

Our conclusion that an intact SH3 domain binding site is not a major factor in determining the level of HIV-1 replication suggests that there is little or no selection pressure for reversion of the alanines to prolines. LAINefP72A/ P75A virion RNA from plasma of the LAINefP72A/P75A infected mice from Figures 7 and 8 was processed for sequencing. No nucleotide changes in nef were noted through six weeks for the entire nef sequence from all four mice. Also, no changes were seen to fourteen weeks for three of four mice (not shown). At week eight, however, nef sequence from one of the four mice infected with the P72A/P75A mutant virus had a clear shift from guanine to mostly cytosine at the first base of the codon for position 75 (Figure 9). This transversion converted the mutant alanine codon (GCT) to the wild type proline codon (CCT). Even though the $\mathrm{CD}^{+} \mathrm{T}$ cells in LAINefP72A/ P75A infected mice were nearly depleted, we continued monitoring the infection past eight weeks to determine if further mutations would occur during LAINefP72A/ P75A infection. Interestingly, for the mouse presented

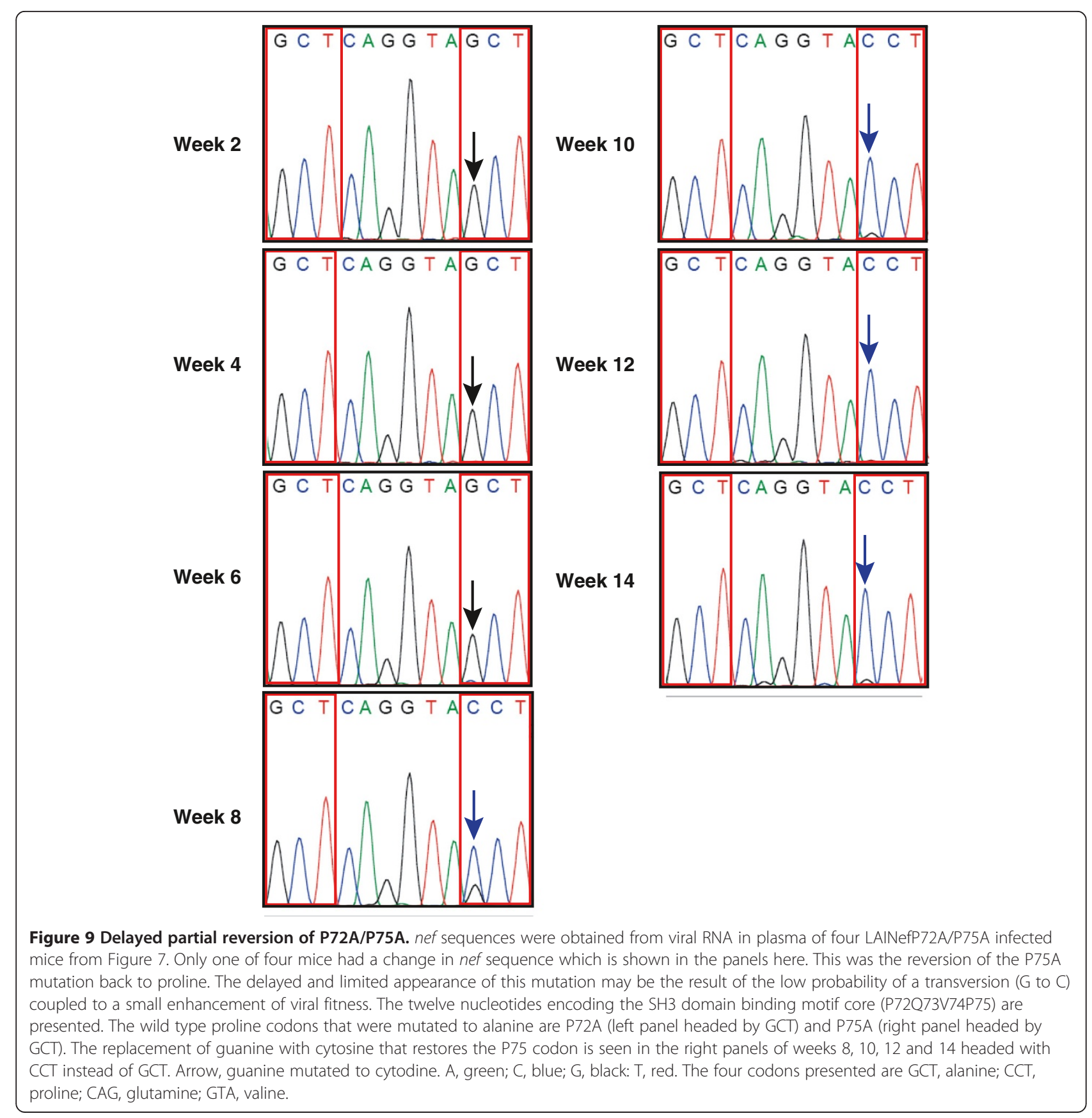


in Figure 9, the virus with an alanine codon at 72 and proline codon at 75 completely replaced the input virus but failed to revert the alanine codon at position 72 (Figure 9, Weeks 10-14). There were no other changes in the nef sequence from this mouse (not shown). Since no reversion to original SH3 domain binding site (P72/P75) occurred within the eight week time frame, the high levels of viral replication and peripheral blood $\mathrm{CD} 4^{+} \mathrm{T}$ cell depletion could not be explained by appearance of wild type virus. Thus, our results support a model where CD4 downregulation plus one or a few additional activities- not dependent on the SH3 domain binding site- largely account for Nef's impact on viral replication and/or pathogenesis. Loss of the capacity for SH3 domain binding has little effect on viral replication and pathogenesis and exhibits at best a small reduction in viral fitness.

\section{Discussion}

Previously, we established that there are large phenotypic differences between infection of BLT mice with wild type LAI and the nef-defective LAINefdd in vivo [44]. LAI replicates to high viral loads concomitantly with aggressive and systematic depletion of $\mathrm{CD}_{4}^{+} \mathrm{T}$ cells and $\mathrm{CD}_{4}{ }^{+} \mathrm{CD}^{+}{ }^{+}$thymocytes. LAINef $d d$ exhibits 6-7 fold lower peak viral loads and has little to no capacity to deplete $\mathrm{CD} 4^{+} \mathrm{T}$ cells or thymocytes [44]. These two large effects of Nef make it feasible to characterize the importance of Nef's individual activities in BLT mice [5]. Here, we have demonstrated a third important property of nef in the BLT mouse model- the ability to evolve and restore functionality. Viruses expressing Nef proteins have a decisive replicative advantage over the frame-shifted LAINeffs and replace the nef-defective virus within a few weeks. Hence, in seven mice, the input LAINeff $s$ was lost after four weeks with either LAINeffs $\Delta-1$ (six mice) or LAINeff $s \Delta-13$ (one mouse) being the sole virus in peripheral blood. By eight weeks, four of seven mice further evolved to be predominantly wild type virus.

The strong in vivo selection of LAINeffs $s-1$ and LAI$\operatorname{Nef} f s \Delta-13$ over LAINeffs led us to characterize these in vivo selected mutant proteins in vitro. We discovered them to be stable but with a total loss of CD4 downregulation activity. Three other in vitro Nef activities, MHCI downregulation, PAK2 activation and enhancement of virion infectivity, remained intact. When BLT mice are infected with LAINeff $s \Delta-1$ and LAINef $f s \Delta-13$, we observed an approximate 3-fold reduction in peak viral load and a partial loss of $\mathrm{CD}_{4}^{+} \mathrm{T}$ cells and $\mathrm{CD} 4^{+} \mathrm{CD} 8^{+}$thymocytes relative to that observed for LAI. These observations suggest that the in vivo selection of the two viruses with mutant nefs relative to LAINeffs relied on activities beyond $\mathrm{CD} 4$ downregulation. Conversely, the partial reduction of Nef effectiveness observed for LAINeff $s \Delta-1$ and LAINef $f_{s} \Delta-13$ demonstrates a significant role for CD4 downregulation.

Our data provided evidence that there is selective pressure for restoration of Nef activities other than CD4 downregulation. The identity of these activities is unknown. We considered likely candidates to be one or more of the SH3 domain binding site dependent activities. These activities include enhancement of virion infectivity [21,25,37], PAK2 activation [21-23], upregulation of FasL and PD1 [28,29], activation of Hck [31], downregulation of MHCI [32-34] and Lck-dependent activation Ras-Erk signaling to promote the production of the T lymphocyte survival factor IL-2 [62,63]. We mutated prolines 72 and 75 to alanine to prevent interactions between Nef and host cell SH3 domain proteins $[21,22]$. This mutation did not exhibit a negative effect on Nef function in BLT mice. One explanation for this counter intuitive observation is that high levels of replication and rapid reduction in $\mathrm{CD} 4^{+} \mathrm{T}$ cell and $\mathrm{CD} 4^{+} \mathrm{CD} 8^{+}$thymocytes depend on only a few Nef activities.

Future studies with BLT mice will investigate Nef activities that are potentially responsible for the $\mathrm{CD} 4$ downregulationindependent aspects of Nef function in vivo. Possible activities include elevated secretion of exosomes, blocking the anti-viral effect of autophagy and inhibition of ASK1 [64-69]. Conversely, these studies may lead to the important result that known Nef activities may not account for a substantial portion of its impact on HIV-1 infection in vivo [70]. In this regard, our mutational strategy of introducing palindromic insertions into Nef coding sequence can be extended to scan the protein for regions of special significance for viral replication and pathogenesis. The HIV-1/ BLT mice infection model described here is a feasible experimental platform for resolving these questions.

\section{Conclusion}

CD4 downregulation activity accounts for approximately half of Nef's capacity to enhance viral replication and deplete $\mathrm{CD}_{4}^{+} \mathrm{T}$ cells and $\mathrm{CD} 4^{+} \mathrm{CD} 8^{+}$thymocytes. This result is consistent with the high degree of conservation of the CD4 downregulation activity. Identities of the Nef activities that account for the remainder of Nef's effects are unknown. We found these latter activities which are present in LAINeff $s \Delta-1$ and LAINeff $s \Delta-13$ provide the virus a strong selective advantage over LAINeffs that is fully defective for Nef expression. In addition, wild type virus, expressing a fully active Nef, out-competes virus expressing Nef specifically defective for CD4 downregulation. We tested the Nef activities dependent on the $\mathrm{SH} 3$ domain binding site because the corresponding amino acid sequence in the protein is highly conserved. However, the virus with nef mutated for $\mathrm{SH} 3$ domain binding was essentially wild type in its ability to enhance viral replication and deplete $\mathrm{CD}_{4}^{+} \mathrm{T}$ cells and $\mathrm{CD} 4^{+}$ 
$\mathrm{CD}^{+}$thymocytes. Selective pressure for the mutant nef to revert to wild type was low. It is critical to determine which Nef activities or activities that do not depend on $\mathrm{SH} 3$ domain protein binding yet have major impacts on viral replication and pathogenesis.

\section{Methods}

\section{Preparation of BLT humanized mice}

BLT humanized mice were prepared as previously described [40-42,44,57,71-77]. Briefly, thymus/liver implanted or NOD/SCID IL- $2 \gamma^{-/-}$mice (The Jackson Laboratories, Bar Harbor, ME) were transplanted with autologous human $\mathrm{CD}^{+}{ }^{+}$cells isolated from fetal liver (Advanced Bioscience Resources, Alameda, CA). Human reconstitution in the peripheral blood of these mice was monitored periodically by flow cytometry (FACSCanto; BD Biosciences). Mice were maintained either at the Animal Resources Center, UT Southwestern Medical Center at Dallas (UTSWMC) or at the Division of Laboratory Animal Medicine, University of North Carolina at Chapel Hill (UNC-CH) in accordance with protocols approved by the UTSWMC or UNC-CH Institutional Animal Care and Use Committees.

To ensure genetic diversity, fifteen different tissue donors were used to generate five groups of mice used for the experiments presented in this manuscript. The overall level of engraftment for all the mice used in this manuscript was $60.9 \% \pm 3.2 \% \quad(n=27)$. None of the groups (Naïve, LAI, LAINef $f_{s} \Delta-1, \operatorname{LAINef} f_{s} \Delta-13$ and LAINefP72A/P75A) had significantly different engraftment levels compared to any of the other groups ( $\mathrm{p} \geq 0.1535)$. All groups had at least two different human genetic backgrounds included in the evaluation of infection. LAI$\operatorname{Nef} f s \Delta-1$, LAINeff $s \Delta-13$ and LAINefP72A/P75A infected groups each shared a common donor with the LAI infected group.

\section{Cell lines and culture conditions}

HeLa Magi and TZM-bl cells were maintained in Dulbecco's modified Eagle's medium (DMEM; Cellgro, Herndon, VA) supplemented with $10 \%$ fetal bovine serum (FBS; Cellgro), $100 \mathrm{IU} / \mathrm{ml}$ of penicillin, $100 \mu \mathrm{g} / \mathrm{ml}$ streptomycin, and $2 \mathrm{mM}$ glutamine (Cellgro) in $10 \% \mathrm{CO}_{2}$ at $37^{\circ} \mathrm{C}$. Similarly, $293 \mathrm{~T}$ cells were cultured under the same conditions as TZM-bl and HeLa Magi cells but in 5\% $\mathrm{CO}_{2}$. The human CEM T cell line was cultured in RPMI 1640 medium supplemented with $10 \%$ fetal bovine serum (Hyclone), 50 IU of penicillin per $\mathrm{ml}, 50 \mu \mathrm{g}$ streptomycin per $\mathrm{ml}, 2 \mathrm{mM}$ L-glutamine and $1 \mathrm{mM}$ sodium pyruvate in $10 \% \mathrm{CO}_{2}$ at $37^{\circ} \mathrm{C}$.

\section{Proviral clones}

The proviral clone, pLAI (accession \# K02013), was described by Peden et al. [78]. pLAINeffs was constructed to be defective for nef by cutting with XhoI, filling in with Klenow and re-ligating. This leaves nef sequence intact but introduces a four-base frame-shift after nef codon 35 (Additional file 1). The one base deletion (8501) and thirteen base deletion (8511-8523) found in nef sequences from LAINeffs infected mice were inserted into pLAINef $f s$ by site directed mutagenesis to produce pLAI$\operatorname{Nef} f s \Delta-1$ and pLAINeff $s \Delta-13$, respectively.

Virus production, exposure of BLT mice to HIV-1 $1_{\text {LAI }}$ and HIV-1 $1_{\text {LAI }}$ with mutated nefs, tissue harvesting and flow cytometric analyses

Stocks of LAI, LAINef $f s, \operatorname{LAINef} f s \Delta-1, \operatorname{LAINef} f s \Delta-13$ and LAINefP72A/P75A were prepared and titered as we previously described [54,79]. Briefly, proviral clones were transfected into $293 \mathrm{~T}$ cells. Viral supernatant was collected 48 hours after transfection and diluted in Dulbecco's modified Eagle's medium (DMEM) supplemented with 10\% fetal bovine serum, $100 \mathrm{IU}$ penicillin $/ \mathrm{ml}, 100 \mu \mathrm{g} / \mathrm{ml}$ streptomycin, and $2 \mathrm{mM}$ glutamine. TZM-bl cells were infected in 12-well tissue culture plates with $0.4 \mathrm{ml}$ of virus at multiple dilutions in medium for two hours. Then, $1.0 \mathrm{ml}$ of supplemented DMEM was added and the plates incubated overnight. Virus containing medium was removed the next day, replaced with fresh DMEM plus $10 \%$ fetal bovine serum and the incubation continued for 24 hours. The cells were fixed and stained with 5-bromo-4-chloro-3indolyl- $\beta$-D-galactopyranoside ( 40 hours after first exposure to virus). Individual blue cells were counted directly to determine infectious particles per ml (TCIU). Each titer of these viral stocks was performed in triplicate and at least two different titer determinations were performed for each virus preparation.

Intravenous exposure of BLT mice with infectious virus was conducted via tail vein injection with the indicated tissue culture infectious units (TCIU). Viral load in peripheral blood of infected mice was monitored longitudinally by quantitative real-time PCR using Taqman RNA to- $\mathrm{C}_{\mathrm{T}}{ }^{\mathrm{rm}}$ 1-step kit from Applied Biosystems, USA $[72,73,80]$. The sequences of the forward and reverse primers and the Taqman probe for PCR were: $5^{\prime}$-CATGTTTTCAG CATTATCAGAAGGA-3', 5' -TGCTTGATGTCCCCCCAC T-3', and 5' -FAM CCACCCCACAAGATTTAAACACCAT GCTAA-Q-3', respectively.

$\mathrm{CD}^{+}$and $\mathrm{CD}^{+} \mathrm{T}$ cell levels were monitored by flow cytometric analysis as previously described $[40,57,76]$. Immunophenotyping was performed on blood samples collected longitudinally and on mononuclear cells isolated from tissues at harvest. Whole peripheral blood (PB) from humanized mice was analyzed according to the BD Biosciences Lyse/Wash protocol (Cat. No. 349202) as we have previously described [81]. Briefly, following antibody labeling of whole blood, red blood cells were lysed. The remaining cells were washed, fixed and the sample was analyzed by flow cytometry. Tissue mononuclear cell isolations and immunophenotyping 
analyses were also performed according to published methods $[40,57,76]$. Flow cytometric gating for CD4 and CD8 cell surface expression was performed as follows: (step 1) forward and side scatter properties were utilized to set a live cell gate; (step2) live cells were then analyzed for expression of the human pan-leukocyte marker CD45; (step 3) human leukocytes were then analyzed for hCD3 and (step 4) these T cells or thymocytes were analyzed for hCD4 and hCD8 expression.

The panel of antibodies for analysis of $\mathrm{CD}^{+} \mathrm{T}$ cells double positive for $\mathrm{CD}^{+} 8^{+}$and HLA-DR ${ }^{+}$was CD8 FITC (SK1), HLA-DR, PE (TU36) or IgG2bK PE, CD4 PerCP (SK3), CD3 PE-Cy7 (SK7), CD38 APC (HB7) or IgG1א $\mathrm{APC}$, and CD45 APC-Cy7 (2D1) (all purchased from BD Biosciences). Gating was performed as follows: (step 1) forward and side scatter properties were utilized to set a live cell gate; (step 2) live cells were then analyzed for expression of the human pan-leukocyte marker CD45; (step 3) human leukocytes were then analyzed for CD3; (step 4) T cells were analyzed for CD4 and/or CD8 expression; (step 5) activation of human $\mathrm{CD} 8^{+} \mathrm{T}$ cells was analyzed for HLA-DR and CD38 expression [42]. Gates defining HLA-DR and CD38 expression were set with isotype-matched flourophore-conjugated antibodies.

\section{Viral replication in vitro}

The human T-cell line A3.01 (NIH AIDS Reagent Program) was used to propagate both wild-type and nef-mutant HIV$1_{\text {LAI }}$. Cells were infected with virus stocks at a multiplicity of infection (MOI) of 0.05 in complete RPMI (containing $10 \%$ fetal bovine serum (Hyclone), 50 IU of penicillin per $\mathrm{ml}, 50 \mu$ g streptomycin per $\mathrm{ml}, 2 \mathrm{mM} \mathrm{L}$-glutamine, and $1 \mathrm{mM}$ sodium pyruvate) plus $2 \mu \mathrm{g} / \mathrm{ml}$ polybrene at $37^{\circ} \mathrm{C}$, $5 \% \mathrm{CO}_{2}$ for 4 hours. The cells were washed extensively with PBS and cultured at $37^{\circ} \mathrm{C}, 5 \% \mathrm{CO}_{2}$ in complete RPMI. Cell cultures were passaged twice weekly at which time a sample of the culture supernatant was collected for quantification of viral capsid protein by $2^{\text {gag }}$ ELISA (HIV-1 p24 Antigen Capture Assay (Advance Biosciences Library, Inc., \#5421).

\section{In vitro analysis of Nef activities}

The site directed mutations of nef in pLAINef $f_{s} \Delta-1$, pLAINeff $s \Delta-13$ and pLAINefP72A/P75A were subcloned into pLXSN, a retroviral vector for transduction of CEM $\mathrm{T}$ cells and into pcDNA3.1 for transfection into 293T cells [21]. Assays for CD4 downregulation, MHCI downregulation, and activation of PAK2 were described previously [21]. Enhancement of virion infectivity was determined by single infection assays using HeLa-MAGI indicator cells with virus produced from proviral clones transfected into $293 \mathrm{~T}$ cells $[21,82]$. Protein expression was determined by Western Blot analysis with sheep anti-Nef antibody or mouse monoclonal anti-Nef $[21,83]$.

\section{Sequence analysis of plasma virion RNA}

Viral RNA was extracted from $20 \mu \mathrm{l}$ of plasma from infected mice using the QIAamp Viral RNA Mini kit (Qiagen Sciences, USA). RNA was then reverse transcribed into cDNA, which was then subjected to nested PCR. The outer primers for nef amplification are 5 '-AGCTTGCT CAATGCCACAGCC-3' and 5'-GCTGCATATAAGCAG CTGCTTTTTG-3'. The inner primers are 5'-TAGAGC TATTCGCCACATACC-3' and 5'-GCTTGCTACAAGG GACTTTCCGC-3'. Gel purified PCR products were sequenced and the sequences were aligned to $\mathrm{HIV}_{\mathrm{LAI}}$ sequences to determine if nucleotide changes had occurred.

\section{Statistics}

Mann-Whitney tests were performed in Prism version 5 (Graph Pad). All data plotted as mean \pm S.E.M.

\section{Additional file}

Additional file 1: Insertion of a palindromic frame shift into Nef.

\section{Competing interests}

The authors declare that they have no competing interests.

\section{Authors' contributions}

RLW, WZ, PWD, JFK and JLF performed experiments. JLF, RLW and JVG designed experiments. RLW, PWD, JLF, and JVG analyzed the data. PWD, JLF and JVG wrote the manuscript. All authors read and approved the final manuscript.

\section{Acknowledgments}

This work was supported by grant Al33331 from the National Institute of Allergy and Infectious Diseases of the National Institutes of Health, USA and UNC CFAR P30 A1504410. RLW is supported by NIH Virology Training Grant 5T32A1007419.

Received: 16 August 2013 Accepted: 23 October 2013

Published: 30 October 2013

\section{References}

1. Calugi G, Montella F, Favalli C, Benedetto A: Entire genome of a strain of human immunodeficiency virus type 1 with a deletion of nef that was recovered 20 years after primary infection: large pool of proviruses with deletions of env. J Virol 2006, 80:11892-11896.

2. Gorry PR, MCPhee DA, Verity E, Dyer WB, Wesselingh SL, Learmont J, Sullivan JS, Roche M, Zaunders JJ, Gabuzda D, et al: Pathogenicity and immunogenicity of attenuated, nef-deleted HIV-1 strains in vivo. Retrovirology 2007, 4:66.

3. Kirchhoff F, Greenough TC, Brettler DB, Sullivan JL, Desrosiers RC: Brief report: absence of intact nef sequences in a long-term survivor with nonprogressive HIV-1 infection. N Engl J Med 1995, 332:228-232.

4. Kondo M, Shima T, Nishizawa M, Sudo K, Iwamuro S, Okabe T, Takebe Y, Imai M: Identification of attenuated variants of HIV-1 circulating recombinant form 01_AE that are associated with slow disease progression due to gross genetic alterations in the nef/long terminal repeat sequences. J Infect Dis 2005, 192:56-61.

5. Abraham L, Fackler OT: HIV-1 Nef: a multifaceted modulator of T cell receptor signaling. Cell Commun Signal 2012, 10:39.

6. Arhel NJ, Kirchhoff F: Implications of Nef: host cell interactions in viral persistence and progression to AIDS. Curr Top Microbiol Immunol 2009 339:147-175.

7. Foster JL, Denial SJ, Temple BR, Garcia JV: Mechanisms of HIV-1 Nef function and intracellular signaling. J Neuroimmune Pharmacol 2011, 6:230-246.

8. Kirchhoff F: Immune evasion and counteraction of restriction factors by HIV-1 and other primate lentiviruses. Cell Host Microbe 2010, 8:55-67. 
9. Laguette N, Bregnard C, Benichou S, Basmaciogullari S: Human immunodeficiency virus (HIV) type-1, HIV-2 and simian immunodeficiency virus Nef proteins. Mol Aspects Med 2010, 31:418-433.

10. Kirchhoff F, Schindler M, Specht A, Arhel N, Munch J: Role of Nef in primate lentiviral immunopathogenesis. Cell Mol Life Sci 2008, 65:2621-2636.

11. Mwimanzi P, Markle TJ, Ogata Y, Martin E, Tokunaga M, Mahiti M, Kuang XT, Walker BD, Brockman MA, Brumme ZL, Ueno T: Dynamic range of Nef functions in chronic HIV-1 infection. Virology 2013, 439:74-80.

12. Heigele A, Schindler M, Gnanadurai CW, Leonard JA, Collins KL, Kirchhoff F: Down-modulation of CD8alphabeta is a fundamental activity of primate lentiviral Nef proteins. J Virol 2012, 86:36-48.

13. Hrecka $K$, Swigut $T$, Schindler M, Kirchhoff F, Skowronski J: Nef proteins from diverse groups of primate lentiviruses downmodulate CXCR4 to inhibit migration to the chemokine stromal derived factor 1. J Virol 2005, 79:10650-10659.

14. Kirchhoff F, Schindler M, Bailer N, Renkema GH, Saksela K, Knoop V, Muller-Trutwin MC, Santiago ML, Bibollet-Ruche F, Dittmar MT, et al: Nef proteins from simian immunodeficiency virus-infected chimpanzees interact with p21-activated kinase 2 and modulate cell surface expression of various human receptors. J Virol 2004, 78:6864-6874.

15. Munch J, Rajan D, Schindler M, Specht A, Rucker E, Novembre FJ, Nerrienet E, Muller-Trutwin MC, Peeters M, Hahn BH, Kirchhoff F: Nef-mediated enhancement of virion infectivity and stimulation of viral replication are fundamental properties of primate lentiviruses. J Virol 2007, 81:13852-13864.

16. Schindler M, Wurfl S, Benaroch P, Greenough TC, Daniels R, Easterbrook P, Brenner M, Munch J, Kirchhoff F: Down-modulation of mature major histocompatibility complex class II and up-regulation of invariant chain cell surface expression are well-conserved functions of human and simian immunodeficiency virus nef alleles. J Virol 2003, 77:10548-10556.

17. Specht A, DeGottardi MQ, Schindler M, Hahn B, Evans DT, Kirchhoff F: Selective downmodulation of HLA-A and -B by Nef alleles from different groups of primate lentiviruses. Virology 2008, 373:229-237.

18. Fackler OT, Moris A, Tibroni N, Giese SI, Glass B, Schwartz O, Krausslich HG: Functional characterization of HIV-1 Nef mutants in the context of viral infection. Virology 2006, 351:322-339.

19. Glushakova S, Munch J, Carl S, Greenough TC, Sullivan JL, Margolis L, Kirchhoff F: CD4 down-modulation by human immunodeficiency virus type 1 Nef correlates with the efficiency of viral replication and with CD4(+) T-cell depletion in human lymphoid tissue ex vivo. J Virol 2001, 75:10113-10117.

20. Lundquist CA, Tobiume M, Zhou J, Unutmaz D, Aiken C: Nef-mediated downregulation of CD4 enhances human immunodeficiency virus type 1 replication in primary T lymphocytes. J Virol 2002, 76:4625-4633.

21. Kuo LS, Baugh LL, Denial SJ, Watkins RL, Liu M, Garcia JV, Foster JL: Overlapping effector interfaces define the multiple functions of the HIV-1 Nef polyproline helix. Retrovirology 2012, 9:47.

22. Manninen A, Hiipakka M, Vihinen M, Lu W, Mayer BJ, Saksela K: SH3-domain binding function of HIV-1 Nef is required for association with a PAK-related kinase. Virology 1998, 250:273-282.

23. Olivieri KC, Mukerji J, Gabuzda D: Nef-mediated enhancement of cellular activation and human immunodeficiency virus type 1 replication in primary T cells is dependent on association with p21-activated kinase 2. Retrovirology 2011, 8:64.

24. O’Neill E, Kuo LS, Krisko JF, Tomchick DR, Garcia JV, Foster JL: Dynamic evolution of the human immunodeficiency virus type 1 pathogenic factor, Nef. J Virol 2006, 80:1311-1320.

25. Pizzato M, Helander A, Popova E, Calistri A, Zamborlini A, Palu G, Gottlinger HG: Dynamin 2 is required for the enhancement of HIV-1 infectivity by Nef. Proc Natl Acad Sci USA 2007, 104:6812-6817.

26. Baur AS, Sawai ET, Dazin P, Fantl WJ, Cheng-Mayer C, Peterlin BM: HIV-1 Nef leads to inhibition or activation of T cells depending on its intracellular localization. Immunity 1994, 1:373-384.

27. Hanna Z, Weng X, Kay DG, Poudrier J, Lowell C, Jolicoeur P: The pathogenicity of human immunodeficiency virus (HIV) type 1 Nef in CD4C/HIV transgenic mice is abolished by mutation of its $\mathrm{SH} 3$-binding domain, and disease development is delayed in the absence of Hck. J Virol 2001, 75:9378-9392.

28. Muthumani K, Choo AY, Hwang DS, Premkumar A, Dayes NS, Harris C, Green DR, Wadsworth SA, Siekierka JJ, Weiner DB: HIV-1 Nef-induced FasL induction and bystander killing requires p38 MAPK activation. Blood 2005, 106:2059-2068.
29. Muthumani K, Choo AY, Shedlock DJ, Laddy DJ, Sundaram SG, Hirao L, Wu L, Thieu KP, Chung CW, Lankaraman KM, et al: Human immunodeficiency virus type 1 Nef induces programmed death 1 expression through a p38 mitogen-activated protein kinase-dependent mechanism. J Virol 2008, 82:11536-11544.

30. Stove V, Naessens E, Stove C, Swigut T, Plum J, Verhasselt B: Signaling but not trafficking function of HIV-1 protein Nef is essential for Nef-induced defects in human intrathymic T-cell development. Blood 2003, 102:2925-2932.

31. Trible RP, Emert-Sedlak L, Smithgall TE: HIV-1 Nef selectively activates Src family kinases Hck, Lyn, and c-Src through direct SH3 domain interaction. J Biol Chem 2006, 281:27029-27038.

32. Blagoveshchenskaya AD, Thomas L, Feliciangeli SF, Hung CH, Thomas G: HIV-1 Nef downregulates MHC-I by a PACS-1- and PI3K-regulated ARF6 endocytic pathway. Cell 2002, 111:853-866.

33. Greenberg ME, lafrate AJ, Skowronski J: The SH3 domain-binding surface and an acidic motif in HIV-1 Nef regulate trafficking of class I MHC complexes. Embo J 1998, 17:2777-2789.

34. Hung CH, Thomas L, Ruby CE, Atkins KM, Morris NP, Knight ZA, Scholz I, Barklis E, Weinberg AD, Shokat KM, Thomas G: HIV-1 Nef assembles a Src family kinase-ZAP-70/Syk-PI3K cascade to downregulate cell-surface MHC-I. Cell Host Microbe 2007, 1:121-133.

35. Jia X, Singh R, Homann S, Yang H, Guatelli J, Xiong Y: Structural basis of evasion of cellular adaptive immunity by HIV-1 Nef. Nat Struct Mol Biol 2012, 19:701-706.

36. Xu W, Santini PA, Sullivan JS, He B, Shan M, Ball SC, Dyer WB, Ketas TJ, Chadburn A, Cohen-Gould L, et al: HIV-1 evades virus-specific IgG2 and $\lg A$ responses by targeting systemic and intestinal $B$ cells via long-range intercellular conduits. Nat Immunol 2009, 10:1008-1017.

37. Goldsmith MA, Warmerdam MT, Atchison RE, Miller MD, Greene WC: Dissociation of the CD4 downregulation and viral infectivity enhancement functions of human immunodeficiency virus type 1 Nef. J Virol 1995, 69:4112-4121.

38. Mangasarian A, Piguet V, Wang JK, Chen YL, Trono D: Nef-induced CD4 and major histocompatibility complex class I (MHC-I) down-regulation are governed by distinct determinants: $\mathrm{N}$-terminal alpha helix and proline repeat of Nef selectively regulate MHC-I trafficking. J Virol 1999, 73:1964-1973.

39. Brainard DM, Seung E, Frahm N, Cariappa A, Bailey CC, Hart WK, Shin HS, Brooks SF, Knight HL, Eichbaum Q, et al: Induction of robust cellular and humoral virus-specific adaptive immune responses in human immunodeficiency virus-infected humanized BLT mice. J Virol 2009, 83:7305-7321

40. Denton PW, Estes JD, Sun Z, Othieno FA, Wei BL, Wege AK, Powell DA, Payne D, Haase AT, Garcia JV: Antiretroviral pre-exposure prophylaxis prevents vaginal transmission of HIV-1 in humanized BLT mice. PLoS Med 2008, 5:e16.

41. Dudek TE, No DC, Seung E, Vrbanac VD, Fadda L, Bhoumik P, Boutwell CL, Power KA, Gladden AD, Battis $L$, et al: Rapid evolution of HIV-1 to functional CD8+ T cell responses in humanized BLT mice. Sci Trans/ Med 2012, 4:143ra198.

42. Long BR, Stoddart CA: Alpha interferon and HIV infection cause activation of human T cells in NSG-BLT mice. J Virol 2012, 86:3327-3336.

43. Murooka TT, Deruaz M, Marangoni F, Vrbanac VD, Seung E, von Andrian UH, Tager AM, Luster AD, Mempel TR: HIV-infected T cells are migratory vehicles for viral dissemination. Nature 2012, 490:283-287.

44. Zou W, Denton PW, Watkins RL, Krisko JF, Nochi T, Foster JL, Garcia JV: Nef functions in BLT mice to enhance HIV-1 replication and deplete CD4 + CD8+ thymocytes. Retrovirology 2012, 9:44.

45. Arganaraz ER, Schindler M, Kirchhoff F, Cortes MJ, Lama J: Enhanced CD4 down-modulation by late stage HIV-1 nef alleles is associated with increased Env incorporation and viral replication. J Biol Chem 2003, 278:33912-33919.

46. Carl S, Greenough TC, Krumbiegel M, Greenberg M, Skowronski J, Sullivan $J$, Kirchhoff F: Modulation of different human immunodeficiency virus type 1 Nef functions during progression to AIDS. J Virol 2001, 75:3657-3665.

47. Kirchhoff F, Easterbrook PJ, Douglas N, Troop M, Greenough TC, Weber J, Carl S, Sullivan JL, Daniels RS: Sequence variations in human immunodeficiency virus type 1 Nef are associated with different stages of disease. J Virol 1999, 73:5497-5508. 
48. Lewis MJ, Balamurugan A, Ohno A, Kilpatrick S, Ng HL, Yang OO: Functional adaptation of Nef to the immune milieu of HIV-1 infection in vivo. $\mathrm{J}$ Immunol 2008, 180:4075-4081.

49. Michael NL, Chang G, d'Arcy LA, Tseng CJ, Birx DL, Sheppard HW: Functional characterization of human immunodeficiency virus type 1 nef genes in patients with divergent rates of disease progression. J Virol 1995, 69:6758-6769.

50. Chateau M, Swanson MD, Garcia JV: Inefficient vaginal transmission of tenofovir-resistant HIV-1. J Virol 2012, 87:1274-1277.

51. Krisko JF, Martinez-Torres F, Foster JL, Garcia JV: HIV restriction by APOBEC3 in humanized mice. PLoS Pathog 2013, 9:e1003242.

52. Garcia JV, Miller AD: Serine phosphorylation-independent downregulation of cell-surface CD4 by nef. Nature 1991, 350:508-511.

53. Schwartz O, Marechal V, Le Gall S, Lemonnier F, Heard JM: Endocytosis of major histocompatibility complex class I molecules is induced by the HIV-1 Nef protein. Nat Med 1996, 2:338-342.

54. Arora VK, Molina RP, Foster JL, Blakemore JL, Chernoff J, Fredericksen BL, Garcia JV: Lentivirus Nef specifically activates Pak2. J Virol 2000, 74:11081-11087.

55. Sawai ET, Baur A, Struble H, Peterlin BM, Levy JA, Cheng-Mayer C: Human immunodeficiency virus type 1 Nef associates with a cellular serine kinase in T lymphocytes. Proc Natl Acad Sci USA 1994, 91:1539-1543.

56. Lundquist CA, Zhou J, Aiken C: Nef stimulates human immunodeficiency virus type 1 replication in primary T cells by enhancing virion-associated gp120 levels: coreceptor-dependent requirement for Nef in viral replication. J Virol 2004, 78:6287-6296.

57. Sun Z, Denton PW, Estes JD, Othieno FA, Wei BL, Wege AK, Melkus MW, Padgett-Thomas A, Zupancic M, Haase AT, Garcia JV: Intrarectal transmission, systemic infection, and CD4+ T cell depletion in humanized mice infected with HIV-1. J Exp Med 2007, 204:705-714.

58. Schindler M, Munch J, Kutsch O, Li H, Santiago ML, Bibollet-Ruche F, Muller-Trutwin MC, Novembre FJ, Peeters M, Courgnaud V, et al: Nef-mediated suppression of $\mathrm{T}$ cell activation was lost in a lentiviral lineage that gave rise to HIV-1. Cell 2006, 125:1055-1067.

59. Schindler M, Schmokel J, Specht A, Li H, Munch J, Khalid M, Sodora DL, Hahn BH, Silvestri G, Kirchhoff F: Inefficient Nef-mediated downmodulation of CD3 and MHC-I correlates with loss of CD4 + T cells in natural SIV infection. PLoS Pathog 2008, 4:e1000107.

60. Casartelli N, Giolo G, Neri F, Haller C, Potesta M, Rossi P, Fackler OT, Doria M: The Pro78 residue regulates the capacity of the human immunodeficiency virus type 1 Nef protein to inhibit recycling of major histocompatibility complex class I molecules in an SH3-independent manner. J Gen Virol 2006, 87:2291-2296.

61. Hanna Z, Kay DG, Rebai N, Guimond A, Jothy S, Jolicoeur P: Nef harbors a major determinant of pathogenicity for an AIDS-like disease induced by HIV-1 in transgenic mice. Cell 1998, 95:163-175.

62. Kouwenhoven A, Minassian VD, Marsh JW: HIV-1 Nef mediates Pak phosphorylation of Mek1 Serine298 and elicits an active phospho-state of Pak2. Curr HIV Res 2013, 11:198-209.

63. Pan X, Rudolph JM, Abraham L, Habermann A, Haller C, Krijnse-Locker J, Fackler OT: HIV-1 Nef compensates for disorganization of the immunological synapse by inducing trans-golgi network-associated Lck signaling. Blood 2012, 119:786-797.

64. Ali SA, Huang MB, Campbell PE, Roth WW, Campbell T, Khan M, Newman G, Villinger F, Powell MD, Bond VC: Genetic characterization of HIV type 1 Nef-induced vesicle secretion. AIDS Res Hum Retroviruses 2010, 26:173-192.

65. Dinkins C, Arko-Mensah J, Deretic V: Autophagy and HIV. Semin Cell Dev Biol 2010, 21:712-718.

66. Geleziunas R, Xu W, Takeda K, Ichijo H, Greene WC: HIV-1 Nef inhibits ASK1-dependent death signalling providing a potential mechanism for protecting the infected host cell. Nature 2001, 410:834-838.

67. Kyei GB, Dinkins C, Davis AS, Roberts E, Singh SB, Dong C, Wu L, Kominami E, Ueno T, Yamamoto A, et al: Autophagy pathway intersects with HIV-1 biosynthesis and regulates viral yields in macrophages. J Cell Biol 2009, 186:255-268.

68. Lenassi M, Cagney G, Liao M, Vaupotic T, Bartholomeeusen $\mathrm{K}$, Cheng $Y$, Krogan NJ, Plemenitas A, Peterlin BM: HIV Nef is secreted in exosomes and triggers apoptosis in bystander CD4+ T cells. Traffic 2010, 11:110-122.

69. Shelton MN, Huang MB, Ali SA, Powell MD, Bond VC: Secretion modification region-derived peptide disrupts HIV-1 Nef's interaction with mortalin and blocks virus and Nef exosome release. J Virol 2012, 86:406-419.
70. Baur AS: HIV-Nef and AIDS pathogenesis: are we barking up the wrong tree? Trends Microbiol 2011, 19:435-440.

71. Denton PW, Krisko JF, Powell DA, Mathias M, Kwak YT, Martinez-Torres F, Zou W, Payne DA, Estes JD, Garcia JV: Systemic administration of antiretrovirals prior to exposure prevents rectal and intravenous HIV-1 transmission in humanized BLT mice. PLoS One 2010, 5:e8829.

72. Denton PW, Olesen R, Choudhary SK, Archin NM, Wahl A, Swanson MD, Chateau M, Nochi T, Krisko JF, Spagnuolo RA, et al: Generation of HIV latency in humanized BLT mice. J Virol 2012, 86:630-634.

73. Denton PW, Othieno F, Martinez-Torres F, Zou W, Krisko JF, Fleming E, Zein S, Powell DA, Wahl A, Kwak YT, et al: One percent tenofovir applied topically to humanized BLT mice and used according to the CAPRISA 004 experimental design demonstrates partial protection from vaginal HIV infection, validating the BLT model for evaluation of new microbicide candidates. J Virol 2011, 85:7582-7593.

74. Kim SS, Peer D, Kumar P, Subramanya S, Wu H, Asthana D, Habiro K, Yang YG, Manjunath N, Shimaoka M, Shankar P: RNAi-mediated CCR5 silencing by LFA-1-targeted nanoparticles prevents HIV infection in BLT mice. Mol Ther 2010, 18:370-376.

75. Lan P, Tonomura N, Shimizu A, Wang S, Yang YG: Reconstitution of a functional human immune system in immunodeficient mice through combined human fetal thymus/liver and CD34+ cell transplantation. Blood 2006, 108:487-492

76. Melkus MW, Estes JD, Padgett-Thomas A, Gatlin J, Denton PW, Othieno FA Wege AK, Haase AT, Garcia JV: Humanized mice mount specific adaptive and innate immune responses to EBV and TSST-1. Nat Med 2006, 12:1316-1322

77. Rajesh D, Zhou Y, Jankowska-Gan E, Roenneburg DA, Dart ML, Torrealba J, Burlingham WJ: Th1 and Th17 immunocompetence in humanized NOD/SCID/IL2rgammanull mice. Hum Immunol 2010, 71:551-559.

78. Peden K, Emerman M, Montagnier L: Changes in growth properties on passage in tissue culture of viruses derived from infectious molecular clones of HIV-1LAI, HIV-1MAL, and HIV-1ELI. Virology 1991, 185:661-672.

79. Wei BL, Denton PW, O'Neill E, Luo T, Foster JL, Garcia JV: Inhibition of lysosome and proteasome function enhances human immunodeficiency virus type 1 infection. J Virol 2005, 79:5705-5712.

80. Palmer S, Wiegand AP, Maldarelli F, Bazmi H, Mican JM, Polis M, Dewar RL, Planta A, Liu S, Metcalf JA, et al: New real-time reverse transcriptase-initiated PCR assay with single-copy sensitivity for human immunodeficiency virus type 1 RNA in plasma. J Clin Microbio/ 2003, 41:4531-4536.

81. Denton PW, Garcia JV: Mucosal HIV-1 transmission and prevention strategies in BLT humanized mice. Trends Microbio/ 2012, 20:268-274.

82. Kimpton J, Emerman M: Detection of replication-competent and pseudotyped human immunodeficiency virus with a sensitive cell line on the basis of activation of an integrated beta-galactosidase gene. J Virol 1992, 66:2232-2239.

83. Chang AH, Hoxie JA, Cassol S, O'Shaughnessy M, Jirik F: Construction of single-chain antibodies that bind an overlapping epitope of HIV-1 Nef. FEBS Lett 1998, 441:307-312.

\section{doi:10.1186/1742-4690-10-125}

Cite this article as: Watkins et al.: In vivo analysis of highly conserved Nef activities in HIV-1 replication and pathogenesis. Retrovirology 2013 10:125

\section{Submit your next manuscript to BioMed Central and take full advantage of:}

- Convenient online submission

- Thorough peer review

- No space constraints or color figure charges

- Immediate publication on acceptance

- Inclusion in PubMed, CAS, Scopus and Google Scholar

- Research which is freely available for redistribution 